\title{
Historical nitrogen fertilizer use in agricultural ecosystems of the contiguous United States during 1850-2015: application rate, timing, and fertilizer types
}

\author{
Peiyu Cao, Chaoqun Lu, and Zhen Yu \\ Department of Ecology, Evolution, and Organismal Biology, Iowa State University, Ames, Iowa, USA \\ Correspondence: Chaoqun Lu (clu@iastate.edu)
}

\begin{abstract}
Received: 28 November 2017 - Discussion started: 18 December 2017
Revised: 11 April 2018 - Accepted: 3 May 2018 - Published: 4 June 2018
\end{abstract}

\begin{abstract}
A tremendous amount of anthropogenic nitrogen $(\mathrm{N})$ fertilizer has been applied to agricultural lands to promote crop production in the US since the 1850s. However, inappropriate $\mathrm{N}$ management practices have caused numerous ecological and environmental problems which are difficult to quantify due to the paucity of spatially explicit time-series fertilizer use maps. Understanding and assessing $\mathrm{N}$ fertilizer management history could provide important implications for enhancing $\mathrm{N}$ use efficiency and reducing $\mathrm{N}$ loss. In this study, we therefore developed long-term gridded maps to depict crop-specific $\mathrm{N}$ fertilizer use rates, application timing, and the fractions of ammonium $\mathrm{N}\left(\mathrm{NH}_{4}^{+}-\mathrm{N}\right)$ and nitrate $\mathrm{N}\left(\mathrm{NO}_{3}^{-}-\mathrm{N}\right)$ used across the contiguous US at a resolution of $5 \mathrm{~km} \times 5 \mathrm{~km}$ during the period from 1850 to 2015 . We found that $\mathrm{N}$ use rates in the US increased from $0.22 \mathrm{~g} \mathrm{~N} \mathrm{~m}^{-2} \mathrm{yr}^{-1}$ in 1940 to $9.04 \mathrm{~g} \mathrm{~N} \mathrm{~m}^{-2} \mathrm{yr}^{-1}$ in 2015 . Geospatial analysis revealed that hotspots for $\mathrm{N}$ fertilizer use have shifted from the southeastern and eastern US to the Midwest, the Great Plains, and the Northwest over the past century. Specifically, corn in the "Corn Belt" region received the most intensive N input in spring, followed by the application of a large amount of $\mathrm{N}$ in fall, implying a high $\mathrm{N}$ loss risk in this region. Moreover, spatial-temporal fraction of $\mathrm{NH}_{4}^{+}-\mathrm{N}$ and $\mathrm{NO}_{3}^{-}-\mathrm{N}$ varied largely among regions. Generally, farmers have increasingly favored ammonia $\mathrm{N}$ fertilizers over nitrate $\mathrm{N}$ fertilizers since the $1940 \mathrm{~s}$. The $\mathrm{N}$ fertilizer use data developed in this study could serve as an essential input for modeling communities to fully assess $\mathrm{N}$ addition impacts, and improve $\mathrm{N}$ management to alleviate environmental problems. Datasets used in this study are available at https://doi.org/10.1594/PANGAEA.883585.
\end{abstract}

\section{Introduction}

The development of the Haber-Bosch process in the early 1900 s led to the massive production of relatively cheap nitrogen $(\mathrm{N})$ fertilizer that boosted crop yields (Erisman et al., 2008; Follett et al., 2010). In the US, $\mathrm{N}$ fertilizer input increased from less than $1 \mathrm{Tg} \mathrm{Nyr}^{-1}\left(1 \mathrm{Tg}=10^{12} \mathrm{~g}\right)$ before 1950 to more than $11 \mathrm{Tg} \mathrm{N} \mathrm{yr}^{-1}$ by the beginning of the $21 \mathrm{st}$ century to increase food production (Ruddy et al., 2006). According to Stewart et al. (2005)'s estimation, N fertilizer was responsible for a $26 \%$ production increase in the six major non-leguminous crops in the US. Zhang et al. (2015) estimated that nitrogen use efficiency (NUE) in the US has increased by approximately $30 \%$ over the last 40 years, which can be attributed to adopting crop varieties, increasing irrigation, and improving nutrient management (Van Grinsven et al., 2015). However, nearly half of $\mathrm{N}$ fertilizer input was not utilized by crops (Smil, 1999; Cassman et al., 2002; Tilman et al., 2002; Ciampitti and Vyn, 2014), and a significant amount of $\mathrm{N}$ applied was lost to the environment via nitrification, denitrification, leaching, and volatilization. This has caused numerous environmental and ecological problems, such as greenhouse gas emissions, eutrophication, soil acidification, and a reduction in biodiversity (Mcisaac et al., 2001; Galloway et al., 2003; Bowman et al., 2008).

It is predicted that agricultural production must be doubled by 2050 to meet the demands of growing human population (Alexandratos and Bruinsma, 2012), which would mean that 
NUE in the US needs to increase by $10 \%$ by 2050 (Zhang et al., 2015). Nonetheless, there is limited room for yield increment under such a high level of $\mathrm{N}$ input in most regions of the US because of diminishing returns, that is, decreasing yield increment from increasing $\mathrm{N}$ fertilizer use (Tilman et al., 2002; Ray et al., 2013). A potential rise in NUE may be achievable by improving $\mathrm{N}$ management practices, such as adopting appropriate application timing and $\mathrm{N}$ fertilizer forms. In contrast, the inappropriate configuration of fertilizer use (e.g., rate, application timing, and fraction of $\mathrm{NH}_{4}^{+}$$\mathrm{N}$ and $\mathrm{NO}_{3}^{-}-\mathrm{N}$ ) could increase $\mathrm{N}$ losses. For example, excess $\mathrm{N}$ input can significantly increase the $\mathrm{NO}_{3}^{-}-\mathrm{N}$ leaching to the aquatic systems through drainage (Jaynes et al., 2001), and raise the emission of $\mathrm{N}_{2} \mathrm{O}$ (Davidson, 2009; Millar et al., 2010; Hoben et al., 2011). Moreover, fall application, which is known to have some negative effects because of the timegap between nutrient supply and growth of plants, is still popular in the Midwest due to favorable weather and soil conditions, available labor, and lower fertilizer prices (Dinnes et al., 2002). Such negative impacts including the higher potential for $\mathrm{N}$ losses (e.g., ammonia volatilization and $\mathrm{N}_{2} \mathrm{O}$ emissions) can dramatically reduce NUE (Hao et al., 2001; Randall et al., 2003). Agricultural N losses are also related to the forms of fertilizer applied. For example, ammonium form $\left(\mathrm{NH}_{4}^{+}-\mathrm{N}\right)$ fertilizers such as urea promote rapid volatilization (Vlek and Craswell, 1979; Keller and Mengel, 1986; He et al., 1999), while nitrate form $\left(\mathrm{NO}_{3}^{-}-\mathrm{N}\right)$ fertilizers are the major contributors of $\mathrm{N}$ leaching (Dinnes et al., 2002). In addition, both ammonium $\mathrm{N}$ and nitrate $\mathrm{N}$ fertilizers can contribute to $\mathrm{N}_{2} \mathrm{O}$ emission through nitrification and denitrification under different soil temperature and moisture conditions (Azam et al., 2002; Bouwman et al., 2002; Tenuta and Beauchamp, 2003; Venterea and Stanenas, 2008; Snyder et al., 2009).

To better manage the use of $\mathrm{N}$ fertilizer and minimize the negative impacts, it is important to examine historical $\mathrm{N}$ use within spatial and temporal contexts. Ruddy et al. (2006) and IPNI (2018) derived annual N fertilizer input data in the US at a county-level using the annual commercial fertilizer consumption report in each state provided by the Association of American Plant Food Control Officials (AAPFCO) and the enhanced 1992 National Land Cover Data (NLCDe 92) (Nakagaki and Wolock, 2005). Nevertheless, their study was unable to depict cross-crop divergence in $\mathrm{N}$ fertilizer use, which is critical for identifying areas of $\mathrm{N}$ deficiency and hotspots of overfertilization due to the different responses of crops to N input (Stewart et al., 2005; Deryng et al., 2011; Mueller et al., 2012). In addition, Ruddy et al. (2006) only covered N fertilizer use over a short period, from 1982 to 2001, based on one-phase static land cover map. A long-term $\mathrm{N}$ application history is important for both field investigators and the modeling community to comprehensively examine the cumulative impacts of fertilizer use (Alexander and Smith, 1990; Van Grinsven et al., 2015). Spatially, cropland area change is also an important factor determining the distri- bution of agricultural $\mathrm{N}$ input. Additionally, spatiotemporal maps depicting both application timing and fertilizer forms are essential for accurate assessment of $\mathrm{N}$ losses because of the significant interactions between these two factors (Harrison and Webb, 2001). Nitrogen can be overwhelmingly lost through ammonia volatilization within a few days after application if conditions are suitable (Burch and Fox, 1989; Jarvis and Pain, 1990). For example, Sommer et al. (2004) reported that half of the total $\mathrm{NH}_{3}$ could be lost from urea 2 to 7 days after its application. In addition, nitrate $\mathrm{N}$ fertilizer applied in fall and spring is vulnerable to leaching by following heavy rainfall due to its high mobility. However, there is still a lack of data describing long-term spatially explicit agricultural $\mathrm{N}$ management practices across contiguous US.

To facilitate Earth system modeling and inventory-based studies, we developed a spatially explicit time-series dataset to describe agricultural synthetic $\mathrm{N}$ fertilizer input (rate, application timing, and the fraction of $\mathrm{NH}_{4}^{+}-\mathrm{N}$ and $\mathrm{NO}_{3}^{-}-\mathrm{N}$ ) in the contiguous US at a resolution of $5 \mathrm{~km} \times 5 \mathrm{~km}$ during the period from 1850 to 2015. In this study, we aim at (1) quantifying commercial $\mathrm{N}$ fertilizer use rate in agricultural land across the US and identifying the historical hotspots of $\mathrm{N}$ fertilizer use; (2) examining the geospatial patterns of $\mathrm{N}$ fertilizer application timing nationwide; and (3) examining the spatial and temporal variations in proportions of $\mathrm{NH}_{4}^{+}-\mathrm{N}$ and $\mathrm{NO}_{3}^{-}-\mathrm{N}$ throughout $\mathrm{N}$ fertilizer use history across agricultural regions of the US.

\section{Method}

We generated an annual state-level crop-specific commercial nitrogen $(\mathrm{N})$ use rate from 1850 to 2015 by calculating and gap-filling national total $\mathrm{N}$ fertilizer consumption, national crop-specific $\mathrm{N}$ fertilizer average use rate, and state-level $\mathrm{N}$ fertilizer average use rate from multiple sources. We split the $\mathrm{N}$ use rate generated above into four application timings according to the state-level crop-specific survey data in the latest years. We further calculated $\mathrm{NH}_{4}^{+}-\mathrm{N}$ and $\mathrm{NO}_{3}^{-}-\mathrm{N}$ use rate of the four timings based on state-level fraction of $\mathrm{NH}_{4}^{+}-\mathrm{N}$ and $\mathrm{NO}_{3}^{-}-\mathrm{N}$ estimated from 11 major single $\mathrm{N}$ fertilizer types and their preferred application timings. We spatialized the $\mathrm{N}$ fertilizer use records generated above (including rate, application timing, and $\mathrm{NH}_{4}^{+}-\mathrm{N}$ and $\mathrm{NO}_{3}^{-}-\mathrm{N}$ use rate) to gridded maps based on $1 \mathrm{~km} \times 1 \mathrm{~km}$ historical land cover data of the contiguous US developed by Yu and Lu (2017) (Fig. 1). 


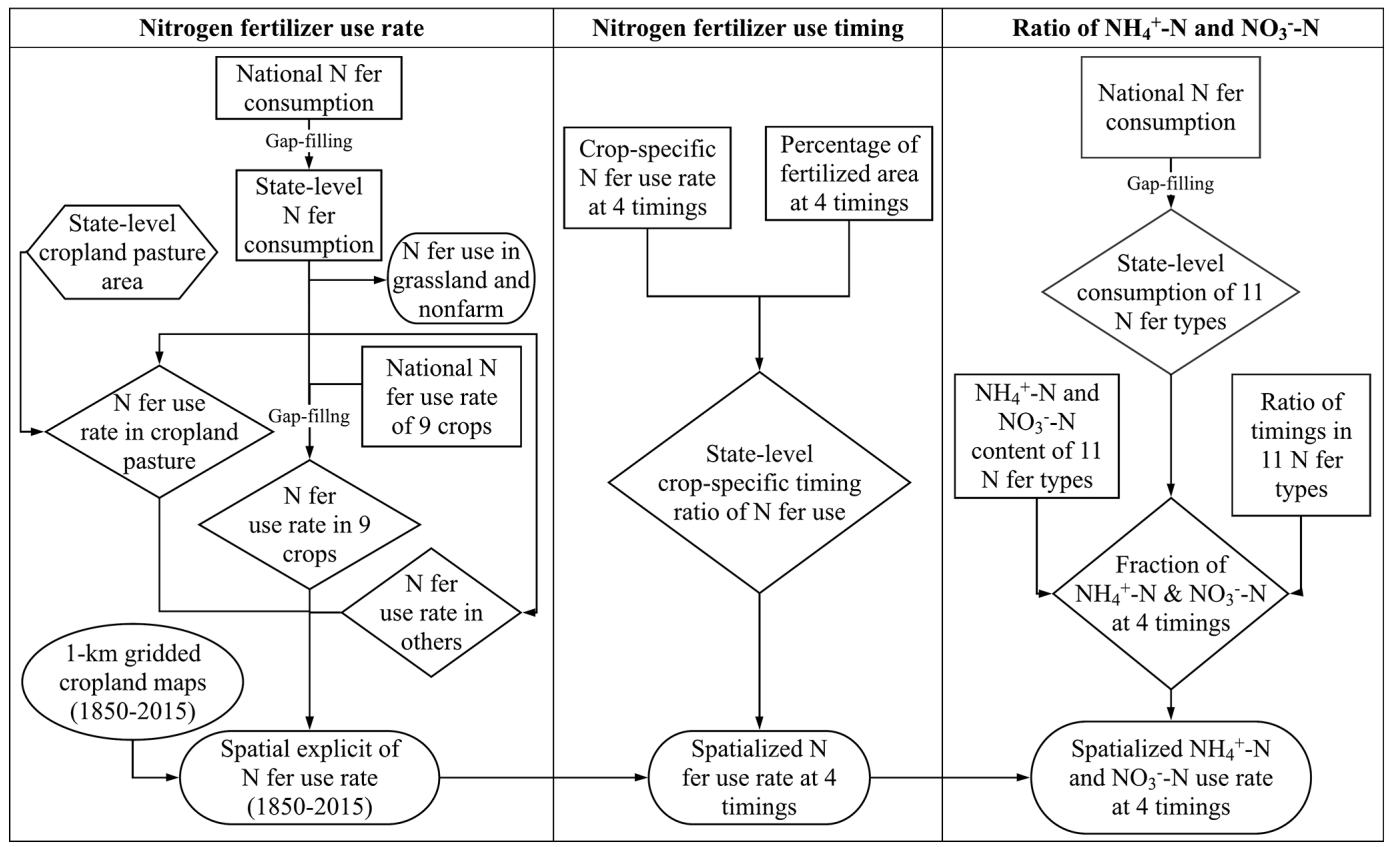

Figure 1. Workflow diagram for developing spatially explicit time series of $\mathrm{N}$ fertilizer use data (including rate, application timing, and $\mathrm{NH}_{4}^{+}-\mathrm{N}$ and $\mathrm{NO}_{3}^{-}-\mathrm{N}$ use rate) in the contiguous US during the period from 1850 to 2015 . " $\mathrm{N}$ fer" is used to refer to $\mathrm{N}$ fertilizer and " 4 timings" refers to fertilizer application during the four application periods discussed in the text.

\subsection{Historical $\mathrm{N}$ fertilizer use rate reconstruction}

\subsubsection{Estimating national commercial $\mathrm{N}$ fertilizer consumption}

By harmonizing the annual national commercial $\mathrm{N}$ consumption from Mehring et al. (1957) for 1850-1951, USDA (1971) for 1952-1959, and USDA-ERS (2013) for 1960-2014, we obtained a N consumption record for the contiguous US from 1850 to 2014.

\subsubsection{Estimating state-level $\mathrm{N}$ fertilizer use rate}

By integrating and gap-filling the annual state-level $\mathrm{N}$ fertilizer consumption from Mehring et al. (1957), USDA (1971), USDA (1977), Brakebill and Gronberg (2017), and national $\mathrm{N}$ consumption generated above, we reconstructed the statelevel $\mathrm{N}$ fertilizer consumption at the contiguous US from 1850 to 2015 (Table S1 Supplement). For the periods pre1930, 1970-1975, and 1978-1987, the state-level N consumptions were unavailable. We assumed that the ratios of state-level $\mathrm{N}$ fertilizer consumption to national total in these missing years are kept consistent with their nearest available years (i.e., ratios of 1969 were applied to 1970-1972 and ratios of 1976 were applied to 1973-1975). By timing the ratio of each state to national $\mathrm{N}$ fertilizer consumption, we then gap-filled the missing years in the state-level $\mathrm{N}$ fertilizer consumption data.
The state-level $\mathrm{N}$ fertilizer consumption generated above contains $\mathrm{N}$ fertilizer use for all crops, cropland pasture, permanent pasture, and non-farm areas (see Supplement Table $\mathrm{S} 2$ for details). We calculated the annual state-level ratio of permanent pasture and non-farm $\mathrm{N}$ fertilizer consumption to total $\mathrm{N}$ fertilizer consumption, respectively, from 1927 to 2015 by harmonizing and gap-filling Mehring et al. (1957), USDA (1957), Ibach et al. (1964), Ibach and Adams (1967), Brakebill and Gronberg (2017), and Heffer et al. (2017). We assumed that the ratio of $\mathrm{N}$ fertilizer use in permanent pasture and non-farm areas before 1927 stayed constant with 1927 and thus, we excluded permanent pasture and non-farm from total $\mathrm{N}$ fertilizer consumption in each state from 1850 to 2015 based on the ratios generated above (Supplement Fig. S1). We divided the historical $\mathrm{N}$ consumption amount by annual cropland area in each state derived from historical land use data in Yu and Lu (2017) to yield the state-level average $\mathrm{N}$ use rates

\subsubsection{Estimating referenced state-level crop-specific N use rate}

Using data from Mehring et al. (1957), USDA (1957), Ibach et al. (1964), Ibach and Adams (1967), USDA-ERS (2013), and USDA-NASS (2017) (Supplement Table S3), we generated national crop-specific fertilizer use rates for the period from 1850 to 2015 . We focused on nine major crop types nationwide including corn, soybean, winter wheat, spring wheat, cotton, sorghum, rice, barley, and durum wheat. We 
further gap-filled the national crop-specific $\mathrm{N}$ use rates by using state-level $\mathrm{N}$ rates derived above, which served as the reference for gap-filling the state-level crop-specific data later.

Mehring et al. (1957) provided national total fertilizer consumption (i.e., nitrogen, phosphate, and potassium) of corn, soybean, wheats (winter wheat, spring wheat, and durum wheat in total), cotton, barley, and rice in 1927, 1938, 1942, 1946, and 1950, and specifically reported the N consumptions in 1950. Thus, the ratio of $\mathrm{N}$ to total fertilizer in 1950 was calculated and applied to determine the $\mathrm{N}$ consumption for the prior 4 reported years. The national $\mathrm{N}$ use rate for each crop type was then calculated by dividing the $\mathrm{N}$ consumption to planting area of each crop for the 5 years during the period from 1927 to 1950 .

Three approaches were adopted to impute the $\mathrm{N}$ use rates in missing years based on the state-level $\mathrm{N}$ use rate derived above. For the period before 1927, the national average crop-specific application rates were unavailable. We therefore used Eq. (1) to retrieve the $\mathrm{N}$ fertilizer use rate of each crop:

Raw data $i=\frac{\text { Referenced trend }_{i}}{\text { Referenced trend }_{i+1}} \times$ Raw data $_{i+1}$,

where "Raw data" refers to the raw data that contains missing values, "Referenced trend" refers to the complete data from which we extracted the changing trend that raw data can refer to, and $i$ refers to the missing data years.

For the period from 1927 to 2015, the cubic spline interpolation method was mainly used to gap-fill $\mathrm{N}$ use rates when data were missing in less than 3 consecutive years, as distance-weighted imputation method may lose its advantage in these cases (Supplement Fig. S2a and b). We assumed the trends of $\mathrm{N}$ application rate were relatively smooth over such a short period. Nonetheless, using the cubic spline interpolation method may fail to reflect sharp variations due to changes in fertilizer price and grain demand during a long period (e.g., > 3 years, Supplement Fig. S2c and d). Therefore, if the missing data were found in more than 3 consecutive years, we assumed the crop-specific $\mathrm{N}$ use rate followed the interannual variation in the state-level rates. We applied the distance-weighted imputation in gap-filling using Eq. (2) by assuming the missing data is closer to the rate of the nearest year as follows:

$$
\begin{aligned}
& \text { Raw data }_{i+k}=\frac{\text { Referenced trend }_{i+k} \times \text { Raw data }_{i}}{\text { Referenced trend }_{i}} \times \frac{k-i}{j-i} \\
& +\frac{\text { Referenced trend }_{i+k} \times \text { Raw data }_{j}}{\text { Referenced trend }_{j}} \times \frac{j-k}{j-i},
\end{aligned}
$$

where "Raw data" refers to the raw data that contains missing values, "Referenced trend" refers to the complete data that provides a reliable changing trend, the years $i$ and $j$ are the beginning and ending year of the gap, and the year $i+k$ is the $k$ th missing year.

\subsubsection{Estimating crop-specific $\mathrm{N}$ use rates at the state level}

The state-level crop-specific $\mathrm{N}$ use rates of nine major crops for the period from 1954 to 2015 were derived from the same five data sources (Supplement Table S3). The survey datasets after 1950 provided commercial $\mathrm{N}$ use rates of nine crops in the croplands that were fertilized. As there is no information to identify which cropland was fertilized spatially, here, we assumed all croplands in each state were fertilized, and then adjusted the rates by multiplying fertilized cropland percentage with application rate.

The state-level N use rate of wheat from 1965 to 1989 reported by USDA-ERS (2013) was the weighted average rate of winter wheat, spring wheat, and durum wheat. We calculated the fraction of $\mathrm{N}$ consumption of each wheat type in each state to total $\mathrm{N}$ consumption of wheats in 1990. The fractions were used to estimate $\mathrm{N}$ consumption for each wheat type during the period. $\mathrm{N}$ use rate of these three wheat types was then calculated as $\mathrm{N}$ consumption divided by planting area of each wheat type.

For the period from 1850 to 1953 , when the state-level $\mathrm{N}$ fertilizer use rates of nine crops were unavailable, we gapfilled the missing years using Eq. (1) based on data from 1954 by using referenced state-level crop-specific rates. To gap-fill the missing years between 1954 and 2015, we first built regression models between the referenced crop-specific rates and raw state-level rates of the nine crops using quadratic, $\mathrm{cu}$ bic, exponential, and logarithmic functions (Supplement Table S4). Models that poorly fitted were discarded. The "bestfit" model was adopted and used to correct the referenced state-level crop-specific $\mathrm{N}$ use rate trend, which was then further used in distance-weighted imputation (Eq. 2) or cubic spline interpolation (as previously stated, for those cases with missing data over 3 consecutive years the former was employed) (see Supplement Fig. S3 for details). The referenced crop-specific rates were used as a general reference trend when all four models were discarded (e.g., soybean and cotton).

We assumed cropland pasture was not fertilized until 1945 due to a lack of area data and low $\mathrm{N}$ use $(<1.5 \%$ of national total $\mathrm{N}$ use in 1942, Mehring et al., 1957). By timing the annual state-level $\mathrm{N}$ consumption with the ratio of cropland pasture $\mathrm{N}$ consumption to total $\mathrm{N}$ consumption in each state for the same year derived from multiple data sources (see Supplement Table S2 and Fig. S1 for details), we obtained the state-level N consumption of cropland pasture from 1945 to 2015 . We then divided the $\mathrm{N}$ consumption by annual cropland pasture area (USDA-NASS, 2017) to generate the statelevel cropland pasture $\mathrm{N}$ use rate. We further calculated $\mathrm{N}$ consumption and crop area of all other crops in each state by subtracting the data from the nine major crops and cropland pasture from the state-level agricultural N consumption (excluding non-farm and permanent pasture). Finally, we gener- 
ated the state-level $\mathrm{N}$ use rate for other crops by dividing the $\mathrm{N}$ consumption amount by the area of "others".

\subsection{Nitrogen application timing}

We adopted single-year application timing information for the nine major crops in each state (i.e., corn, soybean, winter wheat, spring wheat, cotton, sorghum, rice, barley, and durum wheat). According to USDA-ERS (2016), we grouped state-level crop-specific $\mathrm{N}$ fertilizer use into four application timings: fall (previous year), spring (before planting), at planting, and after planting. USDA-ERS (2016) has conducted the survey since 1996 and collected the data periodically for each crop. For example, corn producers were surveyed in 1996-2001, 2006, and 2010 (Supplement Table S5). Because the collected dates varied among different crops in each state, we adopted the latest survey for all nine crops. The raw data include crop-specific fertilizer use rates at four timings and percentages of the fertilized cropland in each state. As there is no available spatial information to identify the fertilized area, we assumed all cropland was fertilized at a lower application rate by multiplying the reported rate by the fertilized cropland percentage for all four application timings (Goebes et al., 2003). We used the fraction of the application rate of each timing to split the annual state-level crop-specific $\mathrm{N}$ use rate generated in Sect. 2.1 into four application timings.

We assumed farmers have the same preference regarding application timing for all crops in each state. We calculated the average application timing fraction based on the fraction of eight crops (excluding winter wheat) generated above for cropland pasture and other crops.

\subsection{Characterizing $\mathrm{NH}_{4}^{+}-\mathrm{N}$ and $\mathrm{NO}_{3}^{-}-\mathrm{N}$ use rates across states and application timings}

\subsubsection{Estimating national consumption of $\mathrm{N}$ fertilizers}

We collected data regarding the national consumption of 11 major single $\mathrm{N}$ fertilizers including anhydrous ammonia (AnA), aqua ammonia (AqA), ammonium nitrate (AN), ammonium sulfate (AS), nitrogen solution (NS), sodium nitrate $(\mathrm{SN})$, urea, calcium nitrate $(\mathrm{CN})$, diammonium phosphate (DAP), monoammonium phosphate (MAP), and ammonium phosphates (APs), since 1900 from Mehring et al. (1957), USDA (1966), USDA-ERS (2013), and FAO (2017) (Supplement Table S6). Among these $11 \mathrm{~N}$ fertilizers, APs refers to the integration of five major forms of ammonium phosphate. Before 1960, the consumption of DAP and MAP was relatively small and was included in the reported APs. However, beginning in 1960, the consumption of these two fertilizers increased sharply and was therefore reported separately. The gaps after 1900, such as the missing CN data from 1954 to 1959, were imputed using Eq. (2) based on the national commercial $\mathrm{N}$ consumption generated in Sect. 2.1.
Before the wide use of the Haber-Bosch process in the US, commercial $\mathrm{N}$ fertilizer was mainly extracted from natural organic products (e.g., Peruvian guano, fish scraps, and dried blood) and mined from mineral deposits (e.g., Chilean saltpeter) (Sheridan, 1979). We consequently assumed that the fractions of $\mathrm{NH}_{4}^{+}-\mathrm{N}$ and $\mathrm{NO}_{3}^{-}-\mathrm{N}$ before 1900 were the same as those reported in 1900 .

\subsubsection{Estimating state consumption of $\mathrm{N}$ fertilizers}

We collected the state-level records of $11 \mathrm{~N}$ fertilizer consumptions from 1946 to 2012 in a 10-year interval from USDA (1966, 1971, and 1977) and AAPFCO (2017) (Supplement Table S7). The consumption data of $\mathrm{CN}$ during the period from 1946 to 1976, and DAP and MAP during the period from 1966 to 1976 were unavailable. Thus, we imputed the missing years with data from 1986 using Eq. (1). Since the ratio of a specific fertilizer type consumed in a certain state to entire nation stayed relatively stable within 1 decade (Supplement Fig. S4), we used a mid-decade (every sixth year in a decade) ratio to represent the annual ratio in this decade and fill the gaps.

It is well known that applying liquid fertilizer (NS) and $\mathrm{NO}_{3}^{-}-\mathrm{N}$ fertilizer (e.g., $\mathrm{SN}$ and $\mathrm{CN}$ ) in fall and spring increase the risk of $\mathrm{N}$ loss (Randall et al., 2003; Randall and Sawyer, 2008). Therefore, preferred application timings vary among different $\mathrm{N}$ fertilizers. To characterize the use of $\mathrm{N}$ fertilizer types in different application timings, we split the consumptions of each $\mathrm{N}$ fertilizer type into four timings according to the Agronomy Guide for types and uses of nitrogen fertilizers developed by Mengel (2017) (Supplement Table S8). Due to the application of nitrification inhibitors, the convenience of applying fertilizer in fall and spring, and the limitation of using equipment, the practical situations may vary. We considered a few practical situations from the survey (Bierman et al., 2012) to adjust the Agronomy Guide and generate application ratios for each $\mathrm{N}$ fertilizer type for the four application timings which are closer to actual management practices (Table 1).

After allocating each of the fertilizer types to the four application timings, we calculated the state consumption of ammonium $\mathrm{N}\left(\mathrm{NH}_{4}^{+}-\mathrm{N}\right)$ and nitrate $\mathrm{N}\left(\mathrm{NO}_{3}^{-}-\mathrm{N}\right)$ at each timing based on the $\mathrm{N}$ content and the $\mathrm{N}$ form of each fertilizer type listed in Table 2 (USDA-NRCS, 2017). Finally, we calculated the fraction of $\mathrm{NH}_{4}^{+}-\mathrm{N}$ and $\mathrm{NO}_{3}^{-}-\mathrm{N}$ to total $\mathrm{N}$ consumption respectively, and then obtained the use rate of $\mathrm{NH}_{4}^{+}-\mathrm{N}$ and $\mathrm{NO}_{3}^{-}-\mathrm{N}$ at each timing for all crops.

\subsection{Spatializing state-level crop-specific $\mathrm{N}$ fertilizer input to gridded maps}

For spatial analysis, we downscaled the imputed state-level crop-specific $\mathrm{N}$ management data to gridded maps based on $1 \mathrm{~km} \times 1 \mathrm{~km}$ historical land cover data (including crop density and crop type distribution maps) of the contiguous US 
Table 1. Application timing ratio of $11 \mathrm{~N}$ fertilizer types. Ammonium phosphates are the integration of ammonium phosphate compounds in different formula.

\begin{tabular}{lrrrr}
\hline Fertilizer material & Fall & Spring & At planting & After planting \\
\hline Dry solid forms & & & & \\
\hline Ammonium nitrate & 0 & 0.3 & 0.35 & 0.35 \\
Ammonium sulfate & 0.25 & 0.25 & 0.25 & 0.25 \\
Sodium nitrate & 0 & 0.3 & 0.35 & 0.35 \\
Urea & 0.05 & 0.85 & 0.05 & 0.05 \\
Calcium nitrate & 0 & 0.3 & 0.35 & 0.35 \\
Diammonium phosphate & 0.25 & 0.25 & 0.25 & 0.25 \\
Monoammonium phosphate & 0.25 & 0.25 & 0.25 & 0.25 \\
Ammonium phosphates & 0.25 & 0.25 & 0.25 & 0.25 \\
\hline Liquid forms & & & & 0.05 \\
\hline Anhydrous ammonia & 0.6 & 0.3 & 0.05 & 0.05 \\
Aqua ammonia & 0.6 & 0.3 & 0.15 & 0.15 \\
Nitrogen solutions & 0.1 & 0.6 & 0.15 & \\
\hline
\end{tabular}

Table 2. The chemical formula, nitrogen content, and nitrogen form of $11 \mathrm{~N}$ fertilizer types. Ammonium phosphates (APs) are the integration of ammonium phosphate compounds in different formula. We assumed its nitrogen content is $15 \%$ from 1900 to 2015 . Although one of the APs is ammonium phosphate nitrate (APN), we still considered APs to be $\mathrm{NH}_{4}^{+}-\mathrm{N}$ due to the fact that APN comprises a very small proportion of APs $(<0.001)$.

\begin{tabular}{llll}
\hline Fertilizer type & Chemical formula & $\begin{array}{l}\text { Nitrogen } \\
\text { content }\end{array}$ & Nitrogen form \\
\hline Anhydrous ammonia & $\mathrm{NH}_{3}$ & $82 \%$ & $\mathrm{NH}_{4}^{+}-\mathrm{N}$ \\
Aqua ammonia & $\mathrm{NH}_{3}$ & $22 \%$ & $\mathrm{NH}_{4}^{+}-\mathrm{N}$ \\
Ammonium nitrate & $\mathrm{NH}_{4} \mathrm{NO}_{3}$ & $34 \%$ & $50 \% \mathrm{NH}_{4}^{+}-\mathrm{N}, 50 \% \mathrm{NO}_{3}^{-}-\mathrm{N}$ \\
Ammonium sulfate & $\left(\mathrm{NH}_{4}\right)_{2} \mathrm{SO}_{4}$ & $21 \%$ & $\mathrm{NH}_{4}^{+}-\mathrm{N}$ \\
Nitrogen solutions & $\mathrm{CO}\left(\mathrm{NH}_{2}\right)_{2}, \mathrm{NH}_{4} \mathrm{NO}_{3}$ & $30 \%$ & $75 \% \mathrm{NH}_{4}^{+}-\mathrm{N}, 25 \% \mathrm{NO}_{3}^{-}-\mathrm{N}$ \\
Sodium nitrate & $\mathrm{NaNO}_{3}$ & $16 \%$ & $\mathrm{NO}_{3}^{-}-\mathrm{N}$ \\
Urea & $\mathrm{CO}\left(\mathrm{NH}_{2}\right)_{2}$ & $46 \%$ & $\mathrm{NH}_{4}^{+}-\mathrm{N}$ \\
Calcium nitrate & $\mathrm{Ca}\left(\mathrm{NO}_{3}\right)_{2}$ & $17 \%$ & $\mathrm{NO}_{3}^{-}-\mathrm{N}$ \\
Diammonium phosphate & $\left(\mathrm{NH}_{4}\right)_{2} \mathrm{HPO}_{4}$ & $18 \%$ & $\mathrm{NH}_{4}^{+}-\mathrm{N}$ \\
Monoammonium phosphate & $\mathrm{NH}_{4} \mathrm{H}_{2} \mathrm{PO}_{4}$ & $11 \%$ & $\mathrm{NH}_{4}^{+}-\mathrm{N}$ \\
Ammonium phosphates & $\left(\mathrm{NH}_{4}\right)_{3} \mathrm{PO}_{4}$, etc. & $15 \%$ & $\mathrm{NH}_{4}^{+}-\mathrm{N}$ \\
\hline
\end{tabular}

from 1850 to 2015 developed by $\mathrm{Yu}$ and $\mathrm{Lu}$ (2017) and Yu et al. (2018). The cropland density maps were reconstructed to represent the area of cropped land each year while excluding summer idle/fallow areas; this was undertaken by incorporating various sources of inventory data and high spatial resolution satellite images. The crop type maps were reconstructed using satellite images and the USDA National Agricultural Statistics Service (NASS) survey data. The statelevel land area of each crop type in each year is consistent with the USDA survey. More details about cropland maps can be found in Yu and Lu (2017) and Yu et al. (2018).

In this paper, for display purpose, we timed the cropland percentage with the $\mathrm{N}$ use rate in each grid to convert the unit of $\mathrm{N}$ use rate from $\mathrm{g} \mathrm{N} \mathrm{m}^{-2}$ cropland area per year to $\mathrm{g} \mathrm{N} \mathrm{m}^{-2}$ land area per year. We then resampled the $\mathrm{N}$ man- agement maps at a $5 \mathrm{~km} \times 5 \mathrm{~km}$ resolution with the average fertilizer use rate depicted in each pixel. To describe the regional difference of $\mathrm{N}$ management in the study area, we partitioned the entire study area into seven regions (Fig. 4): the Northwest (NW), the Southwest (SW), the Northern Great Plains (NGP), the Southern Great Plains (SGP), the Midwest (MW), the Southeast (SE), and the Northeast (NE) according to the US Fourth National Climate Assessment (2017).

\section{Results}

\subsection{Nitrogen fertilizer use rate}

$\mathrm{N}$ fertilizer consumption in the US was very low $\left(<0.3 \mathrm{Tg} \mathrm{N} \mathrm{yr}^{-1}\right)$ from 1850 to 1940 , and then sharply in- 
creased to $9.8 \mathrm{Tg} \mathrm{N} \mathrm{yr}^{-1}$ by 1980 , followed by a slower rise to $11.4 \mathrm{Tg} \mathrm{N} \mathrm{yr}^{-1}$ by 2015 (Fig. 2a). The $\mathrm{N}$ fertilizer use rate followed these total consumption trends and increased from less than $0.01 \mathrm{~g} \mathrm{~N} \mathrm{~m}^{-2} \mathrm{yr}^{-1}$ in 1850 to $9.04 \mathrm{~g} \mathrm{~N} \mathrm{~m}^{-2} \mathrm{yr}^{-1}$ in 2015 (Fig. 2a). In 1960, most agricultural areas received low $\mathrm{N}$ fertilizer input (less than $6 \mathrm{~g} \mathrm{~N} \mathrm{~m}^{-2} \mathrm{yr}^{-1}$ ); however, due to expansion of cropland and the rapid increase in $\mathrm{N}$ fertilizer use from 1960 to 1980 , the area receiving high $\mathrm{N}$ input $\left(2-8 \mathrm{~g} \mathrm{~N} \mathrm{~m}^{-2} \mathrm{yr}^{-1}\right)$ greatly increased in 1980 , and the usage frequency peaked at a few high $\mathrm{N}$ input values (insert figure in Fig. 2a); this may have been caused by intensive fertilizer use in certain crop types (e.g., maize and rice). In 2015, we found that fewer areas were characterized by low to medium-level fertilizer input $\left(<8 \mathrm{~g} \mathrm{~N} \mathrm{~m}^{-2} \mathrm{yr}^{-1}\right)$, and high-level $\mathrm{N}$ fertilizer application $\left(8-18 \mathrm{~g} \mathrm{~N} \mathrm{~m}^{-2} \mathrm{yr}^{-1}\right.$ ) was more widespread compared to both 1960 and 1980 (inset figure in Fig. 2a). From 1940 to 1960, a moderate rise in the application rate was found in almost all crop types with increments ranging from $0.09 \mathrm{~g} \mathrm{~N} \mathrm{~m}^{-2} \mathrm{yr}^{-1}$ in soybean to $5.5 \mathrm{~g} \mathrm{~N} \mathrm{~m}^{-2} \mathrm{yr}^{-1}$ in rice (Fig. 2b). The 2 decades following 1960 , was the period when the most dramatic increase of $\mathrm{N}$ fertilizer use occurred. The average increase during this time was $4.1 \mathrm{~g} \mathrm{~N} \mathrm{~m}^{-2} \mathrm{yr}^{-1}$ with the largest increase found in corn (11.2 $\left.\mathrm{g} \mathrm{N} \mathrm{m}^{-2} \mathrm{yr}^{-1}\right)$, while cotton received relatively stable amounts of $\mathrm{N}$ fertilizer (Fig. 2b). From 1980 to 2015, minor changes $\left(<2 \mathrm{~g} \mathrm{~N} \mathrm{~m}^{-2} \mathrm{yr}^{-1}\right)$ in the application rate of fertilizer were found in corn, yet large increases were seen in rice $\left(7 \mathrm{~g} \mathrm{~N} \mathrm{~m}^{-2} \mathrm{yr}^{-1}\right)$, spring wheat $\left(6.5 \mathrm{~g} \mathrm{~N} \mathrm{~m}^{-2} \mathrm{yr}^{-1}\right)$, and durum wheat $\left(5.2 \mathrm{~g} \mathrm{~N} \mathrm{~m}^{-2} \mathrm{yr}^{-1}\right)$.

Hotspots of $\mathrm{N}$ fertilizer use have shifted from the southeastern and eastern US to the Midwest, the Great Plains, and the Northwest since the 1940s (Fig. 3). Application rates of commercial $\mathrm{N}$ fertilizer were very low (less than $\left.0.2 \mathrm{~g} \mathrm{~N} \mathrm{~m}^{-2} \mathrm{yr}^{-1}\right)$ across the contiguous US before 1940 . Mild increases $\left(1-2 \mathrm{~g} \mathrm{~N} \mathrm{~m}^{-2} \mathrm{yr}^{-1}\right)$ in $\mathrm{N}$ fertilizer use were detected along the west coast and in the southeastern and eastern US in the 1940s. The application rates in these regions showed dramatic increases to above $7 \mathrm{~g} \mathrm{~N} \mathrm{~m}^{-2} \mathrm{yr}^{-1}$ by 1980. In comparison, the Midwest received a $\mathrm{N}$ fertilizer input of over $10 \mathrm{~g} \mathrm{~N} \mathrm{~m}^{-2} \mathrm{yr}^{-1}$, and the Southern Great Plains, the southern region of the Northern Great Plains, and the Northwest received $\mathrm{N}$ fertilizer at a rate of $4-7 \mathrm{~g} \mathrm{~N} \mathrm{~m}^{-2} \mathrm{yr}^{-1}$ on average from 1960 to 1980 . Not surprisingly, the most intensive N input was found in the central "Corn Belt" (Iowa, Illinois, Nebraska, and Minnesota) pinpointing the Midwest as the $\mathrm{N}$ fertilizer use hotspot in the US after 2000.

\subsection{Application timing}

$\mathrm{N}$ fertilizer application rate in the four timings varied among regions and time periods. Here we present the seasonal variation of agricultural $\mathrm{N}$ input for the year 2015 as an example (Fig. 4). The contiguous US generally received low $\mathrm{N}$ input $\left(<0.5 \mathrm{~g} \mathrm{~N} \mathrm{~m}^{-2} \mathrm{yr}^{-1}\right)$ in fall, except California, North Dakota, the Midwest, and the Southern Great Plains
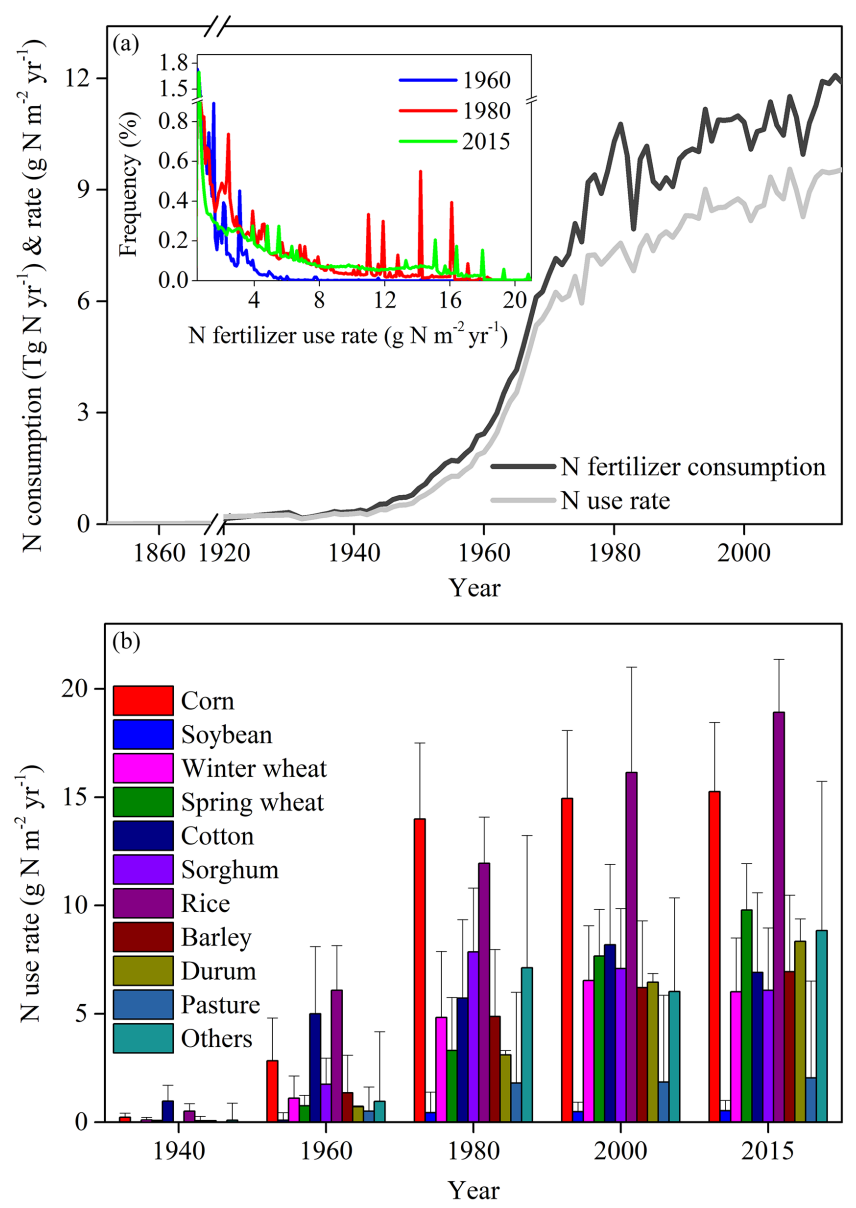

Figure 2. Time series of $\mathrm{N}$ fertilizer use in the US: (a) national commercial $\mathrm{N}$ fertilizer consumption and use rate of the contiguous US from 1850 to 2015 derived from this study (figure inset provides the $\mathrm{N}$ fertilizer rate distribution across the contiguous US in the years 1960, 1980, and 2015); (b) national crop-specific N fertilizer application rate (error bars indicate standard error among states in 1 year).

$\left(2-4 \mathrm{~g} \mathrm{~N} \mathrm{~m}^{-2} \mathrm{yr}^{-1}\right)$. Some areas in Washington, eastern Arkansas and southern Louisiana even received a fertilizer input of more than $4 \mathrm{~g} \mathrm{~N} \mathrm{~m}^{-2} \mathrm{yr}^{-1}$. In comparison, the majority of $\mathrm{N}\left(>4 \mathrm{~g} \mathrm{~N} \mathrm{~m}^{-2} \mathrm{yr}^{-1}\right)$ was applied in spring before planting, and the most intensive application took place in the Midwest, the Northern Great Plains, the Northwest, northern Kentucky, and parts of California, Florida, Arkansas and Louisiana (Fig. 4b). A small amount of $\mathrm{N}\left(<1 \mathrm{~g} \mathrm{~N} \mathrm{~m}^{-2} \mathrm{yr}^{-1}\right)$ was applied at planting in most areas (Fig. 4c), although exceptions were found in the Northern Great Plains, northern California, and Washington $\left(>3 \mathrm{~g} \mathrm{~N} \mathrm{~m}^{-2} \mathrm{yr}^{-1}\right)$. In comparison, intensive $\mathrm{N}$ use $\left(>4 \mathrm{~g} \mathrm{~N} \mathrm{~m}^{-2} \mathrm{yr}^{-1}\right)$ after planting was identified in the eastern Midwest, the southern region of the Northern Great Plains, Idaho, California, and the western and southeastern parts of the Southeast (Fig. 4d). 


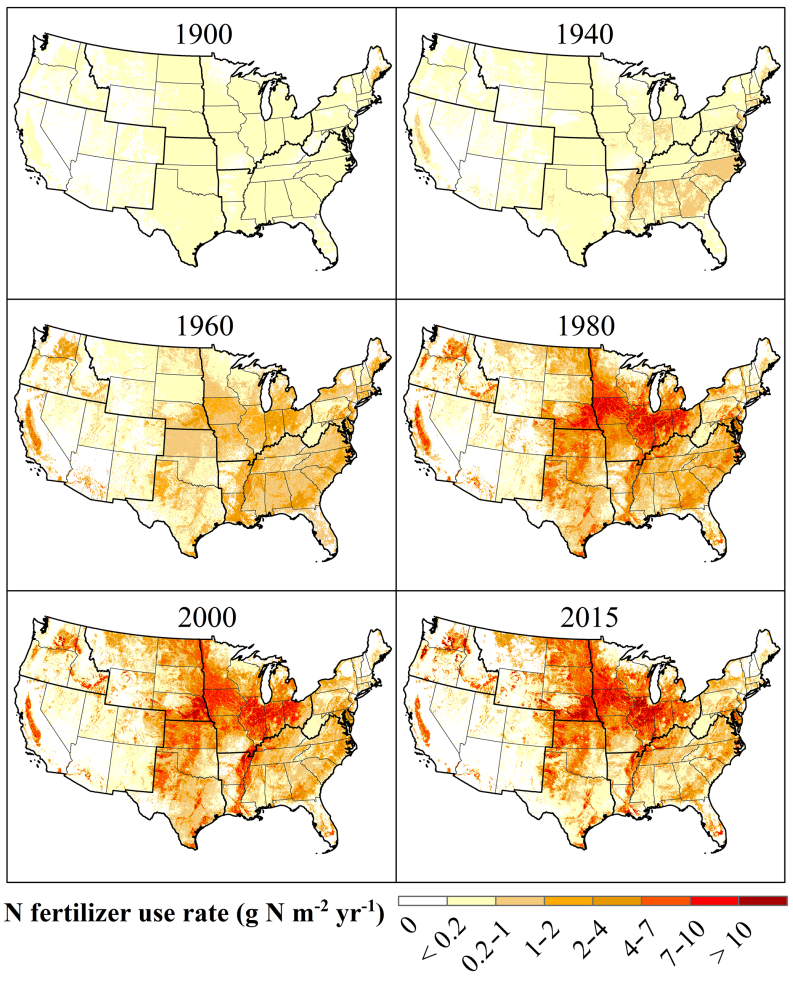

Figure 3. Spatial distribution of $\mathrm{N}$ fertilizer uses in the contiguous US from 1900 to 2015. Values represent agricultural average $\mathrm{N}$ use rate over all crops in each $5 \mathrm{~km}$ by $5 \mathrm{~km}$ grid cell.

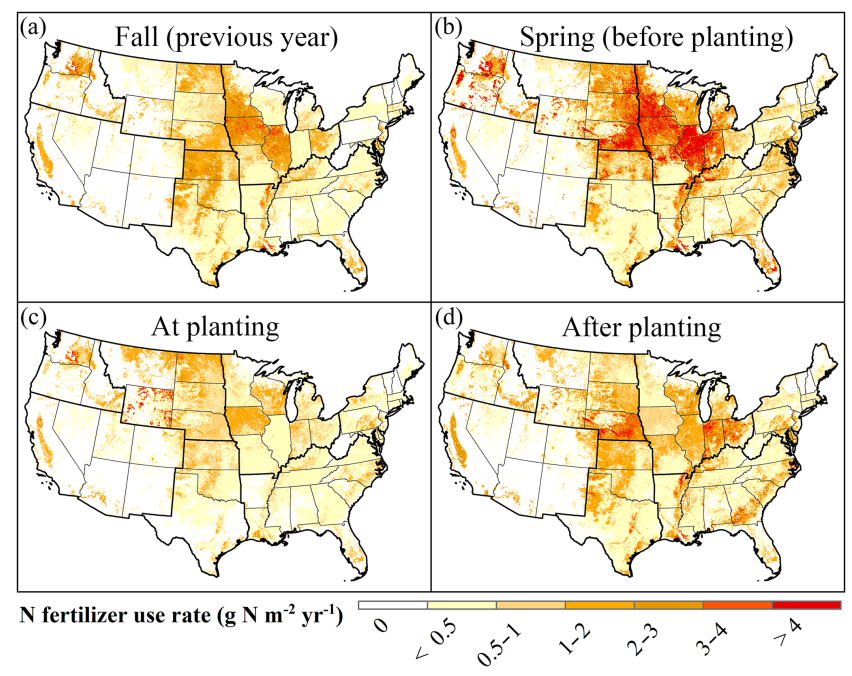

Figure 4. Geographic distribution of the $\mathrm{N}$ application rate in the four application timings during the year 2015: (a) fall (previous year), (b) spring (before planting), (c) at planting, and (d) after planting.

High N input in fall prevailed in the Southern Great Plains, and Washington (Supplement Fig. S5a), and relatively high portions of $\mathrm{N}$ were also applied in Iowa (31\%) and southern Minnesota (32\%) during this period. In comparison, $\mathrm{N}$ applied in spring dominated across the contiguous US, especially in the Midwest, the Northwest, the eastern Northern Great Plains, Arkansas, and Virginia (>50\%, Supplement Fig. S5b). Nitrogen fertilizer applied at planting, however, was generally found to be low $(<20 \%)$ except in Montana (43\%), Wyoming (40\%), and New York (49\%) (Supplement Fig. S5c). Finally, $\mathrm{N}$ applied after planting was very high $(>50 \%)$ in Ohio, Missouri, West Virginia, Vermont, New Hampshire, and coastal areas of the Southeast (Supplement Fig. S5d).

\subsection{Proportion of $\mathrm{NH}_{4}^{+}-\mathrm{N}$ and $\mathrm{NO}_{3}^{-}-\mathrm{N}$ in fertilizer use}

The fractions of $\mathrm{NH}_{4}^{+}-\mathrm{N}$ and $\mathrm{NO}_{3}^{-}-\mathrm{N}$ varied greatly among seven regions of the US before the 1940s (Fig. 5). Ammonium sulfate was the major $\mathrm{N}$ fertilizer in the Midwest, the Northwest, and the Southwest, rendering high fractions of $\mathrm{NH}_{4}^{+}-\mathrm{N}$ in these regions, while sodium nitrate was popular in the Northeast, the Southeast, and the Southern Great Plains, lowering the $\mathrm{NH}_{4}^{+}-\mathrm{N}$ fraction in these regions. A wide variety of $\mathrm{N}$ fertilizers were adopted from 1940 through to 1980 in all regions, among which the high $\mathrm{NH}_{4}^{+}-\mathrm{N}$ concentration fertilizers such as anhydrous ammonia, ammonium nitrate, and $\mathrm{N}$ solution were favored. Since then, the fractions of $\mathrm{NH}_{4}^{+}-\mathrm{N}$ in the seven regions have remained at high and relatively stable level; however, farmers in these regions have also shifted from multiple nutrient fertilizers toward single nutrient fertilizers with high $\mathrm{N}$ concentrations, such as anhydrous ammonia, $\mathrm{N}$ solution, and urea.

The fraction of $\mathrm{NH}_{4}^{+}-\mathrm{N}$ to total $\mathrm{N}$ use ranged from 0 to 0.65 in the 1900 s to 0.8 to 0.9 after 2010 across the US (Fig. 6). $\mathrm{NH}_{4}^{+}-\mathrm{N}$ fertilizer accounted for about $70 \%$ of the total $\mathrm{N}$ fertilizer used in the Northern Great Plains region in 1900, while the Northeast and the Southeast were dominated by $\mathrm{NO}_{3}^{-}-\mathrm{N}$ fertilizer which accounted for about $95 \%$ of the total $\mathrm{N}$ fertilizer use. These fractions showed a general downward trend during 1920-1940 except for a prominent peak value in 1932. In the following 3 decades from 1940 to 1970 , sharp increases were detected in the Northeast (from 0.21 to 0.75), the Southeast (from 0.09 to 0.75), and the Southern Great Plains (from 0.6 to 0.9). During the period from 1970 to 2015 , the fractions of $\mathrm{NH}_{4}^{+}-\mathrm{N}$ in all seven regions were above 0.8 with four regions exceeding 0.9 (Fig. 6).

The proportion of ammonium $\mathrm{N}$ and nitrate $\mathrm{N}$ fertilizer use varied among regions. We used 2015 as an example to address the spatial variation of dominant fertilizer forms and their application rates across the US (Fig. 7). The ammonium $\mathrm{N}$ fertilizer applied in fall was mainly concentrated in the central area of contiguous US, Washington, and California displayed an application rate of $1-3 \mathrm{~g} \mathrm{~N} \mathrm{~m}^{-2} \mathrm{yr}^{-1}$; however, a small amount of nitrate $\mathrm{N}$ fertilizer $\left(<0.1 \mathrm{~g} \mathrm{~N} \mathrm{~m}^{-2} \mathrm{yr}^{-1}\right)$ was applied in fall across the country except some areas in the Southern Great Plains and the Southeast (0.1$\left.0.5 \mathrm{~g} \mathrm{~N} \mathrm{~m}^{-2} \mathrm{yr}^{-1}\right)$. In comparison, ammonium $\mathrm{N}$ fertilizer was intensively used in spring $\left(>5 \mathrm{~g} \mathrm{~N} \mathrm{~m}^{-2} \mathrm{yr}^{-1}\right)$ in the 

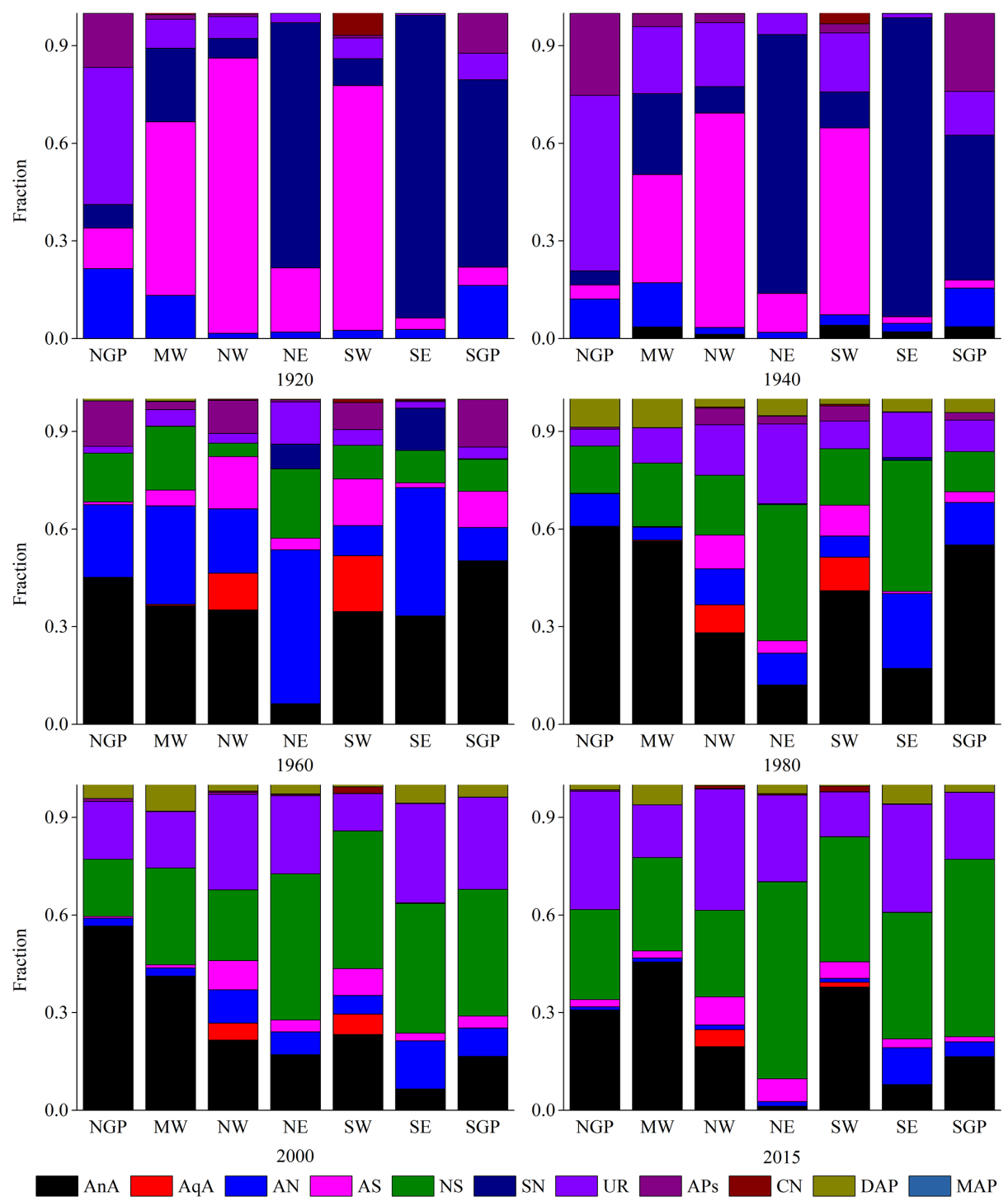

Figure 5. Regional fraction of the $11 \mathrm{~N}$ fertilizer types from 1920 to 2015 . The fraction was the percentage of the $\mathrm{N}$ content of each $\mathrm{N}$ fertilizer to the total $\mathrm{N}$ consumption. The $11 \mathrm{~N}$ fertilizers include anhydrous ammonia (AnA), aqua ammonia (AqA), ammonium nitrate (AN), ammonium sulfate (AS), nitrogen solution (NS), sodium nitrate (SN), urea, calcium nitrate (CN), diammonium phosphate (DAP), monoammonium phosphate (MAP), and ammonium phosphates (APs).

Midwest, the Northern Great Plains, the western Southeast, and the Northwest, where $0.5-1 \mathrm{~g} \mathrm{~N} \mathrm{~m}^{-2} \mathrm{yr}^{-1}$ of nitrate $\mathrm{N}$ fertilizer was applied in the same time period. Highlevel ammonium $\mathrm{N}$ fertilizer applied at planting was mainly distributed in the Northern Great Plains, Iowa, Wisconsin, Washington, and California with application rates of 1$3 \mathrm{~g} \mathrm{~N} \mathrm{~m}^{-2} \mathrm{yr}^{-1}$. High ammonium $\mathrm{N}$ fertilizer use after planting (above $3 \mathrm{~g} \mathrm{~N} \mathrm{~m}^{-2} \mathrm{yr}^{-1}$ ) was found in California, $\mathrm{Ne}$ braska, the Midwest, the Northern Great Plains, the northern Southern Great Plains, and the western and southeastern regions of the Southeast; nitrate $\mathrm{N}$ fertilizer use rates were also high in these areas, especially along the southeast coast (Fig. 7).

\section{Discussion}

\subsection{Comparison with existing $\mathrm{N}$ fertilizer map}

In order to examine the validity of our data, we compared our data with other studies regarding temporal variations and spatial patterns of $\mathrm{N}$ fertilizer use; one regional dataset from IPNI (2018), and two global datasets from Lu and Tian (2017) and Nishina et al. (2017) were utilized (Figs. 8 and 9). IPNI (2018) developed the $\mathrm{N}$ fertilizer use dataset of the US spanning from 1987 to 2012 by adopting the method in Ruddy et al. (2006), which is based on county-level N consumption data derived from state-level $\mathrm{N}$ fertilizer sale and agricultural land acreage. Lu and Tian (2017) and Nishina 


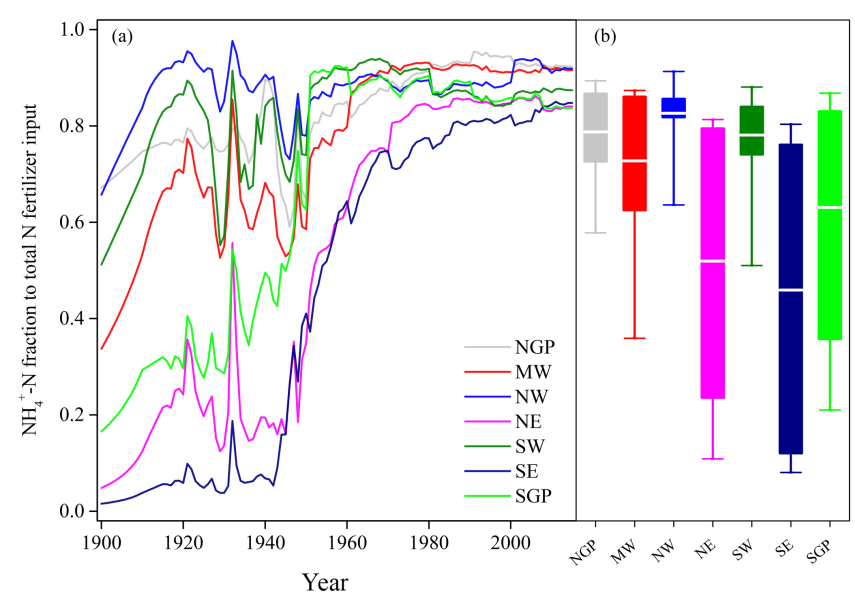

Figure 6. Regional fraction of $\mathrm{NH}_{4}^{+}-\mathrm{N}$ to total $\mathrm{N}$ use in the contiguous US during 1900-2015. (a) Historical change of $\mathrm{NH}_{4}^{+}-\mathrm{N}$ fraction across the seven regions. (b) Boxes include 25-75\% of regional fractions during 1900-2015, white lines are mean values, and whiskers comprise the whole range of data. The seven regions are the Northern Great Plains (NGP), the Midwest (MW), the Northwest (NW), the Northeast (NE), the Southwest (SW), the Southeast (SE), and the Southern Great Plains (SGP).

et al. (2017) derived $\mathrm{N}$ fertilizer use data from the International Fertilizer Association (IFA) and the Food and Agriculture Organization of the United Nations (FAO), respectively. The four datasets showed the same interannual variation of national $\mathrm{N}$ fertilizer consumption from 1961 to 2014 but small difference in magnitude (Fig. 8). The $\mathrm{N}$ fertilizer consumption in our study is slightly smaller than the value from IPNI (2018) except for the year 2001 because our study excluded permanent pasture. The historical $\mathrm{N}$ fertilizer use amount in our study is also lower than Lu and Tian (2017). This is because the $\mathrm{N}$ fertilizer data from $\mathrm{Lu}$ and Tian (2017) contains permanent pasture and non-farm $\mathrm{N}$ fertilizer use and also covers territories of the US rather than just the continental US. While our data is marginally higher than Nishina et al. (2017) in most years, the overall spatial pattern of the $\mathrm{N}$ fertilizer use rate in the contiguous US in 2010 from our study is similar to the other three maps (Fig. 9). This indicates that hotspots of $\mathrm{N}$ fertilizer use occurred in the Midwest, on the west and east coast, and in some parts of the Northwest and the Southern Great Plains. Nevertheless, discrepancies were also found in the magnitude of $\mathrm{N}$ use rates between our data and the other studies: there were only a few states in Lu and Tian (2017) and no states in Nishina et al. (2017) which were reported as having applied over $7 \mathrm{~g} \mathrm{~N} \mathrm{~m}^{-2} \mathrm{yr}^{-1}$ in the year 2010 (Fig. 9c and d). In comparison, two global datasets showed that vast regions received fertilizer at $2-4 \mathrm{~g} \mathrm{~N} \mathrm{~m}^{-2} \mathrm{yr}^{-1}$, in which very little $\mathrm{N}$ fertilizer application was indicated in this study or IPNI (2018). This is because the global cropland maps were based on HYDE 3.2 (Klein Gildewijk, 2016) in Lu and Tian (2017)

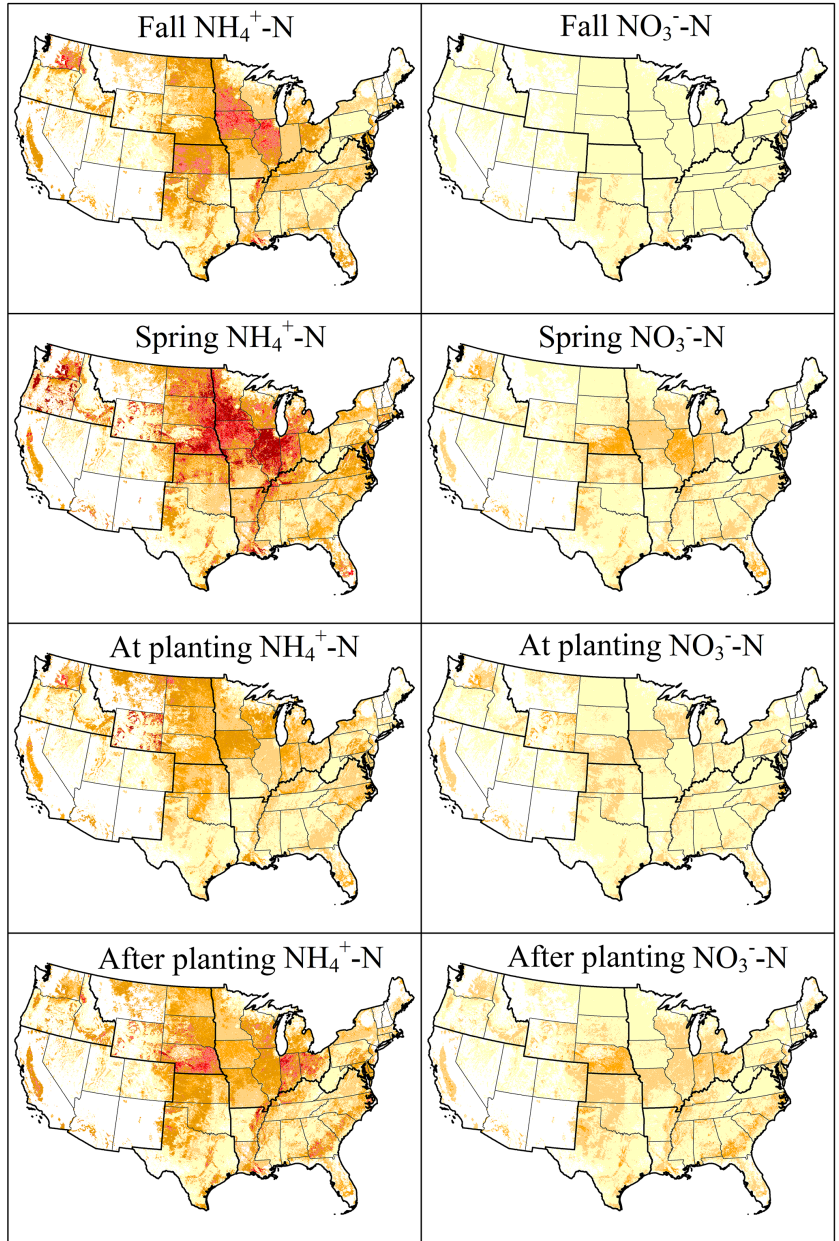

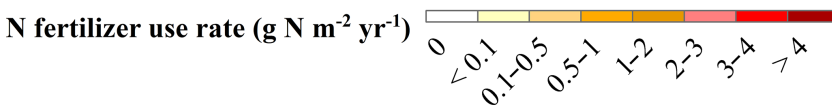

Figure 7. Spatial distribution of $\mathrm{NH}_{4}^{+}-\mathrm{N}$ and $\mathrm{NO}_{3}^{-}-\mathrm{N}$ application rate for the four application timings in 2015.

and HYDE 3.1 (Hurrt et al., 2011) in Nishina et al. (2017). The HYDE data overestimated cropland percentage in low crop-coverage states while underestimating crop percentage in the US "Corn Belt" (Yu and Lu, 2017). This explains the different spatial patterns revealed by these four $\mathrm{N}$ fertilizer datasets, even though their total consumption values are very close nationally. By comparison, our data considers crosscrop divergence in $\mathrm{N}$ fertilizer use, covers longer period, and shows more details with finer resolution.

We further compared our map with that from Ruddy et al. (2006). Ruddy et al. (2006) developed a map showing the spatial patterns of $\mathrm{N}$ fertilizer use rate in the contiguous US in 1997, using the same approach as IPNI (2018) to derived county-level $\mathrm{N}$ use rate, but downscale to gridded maps based on the enhanced 1992 National Land Cover Data (NLCDe 92) (Nakagaki and Wolock, 2005); this approach provides more details regarding spatial $\mathrm{N}$ fertilizer 


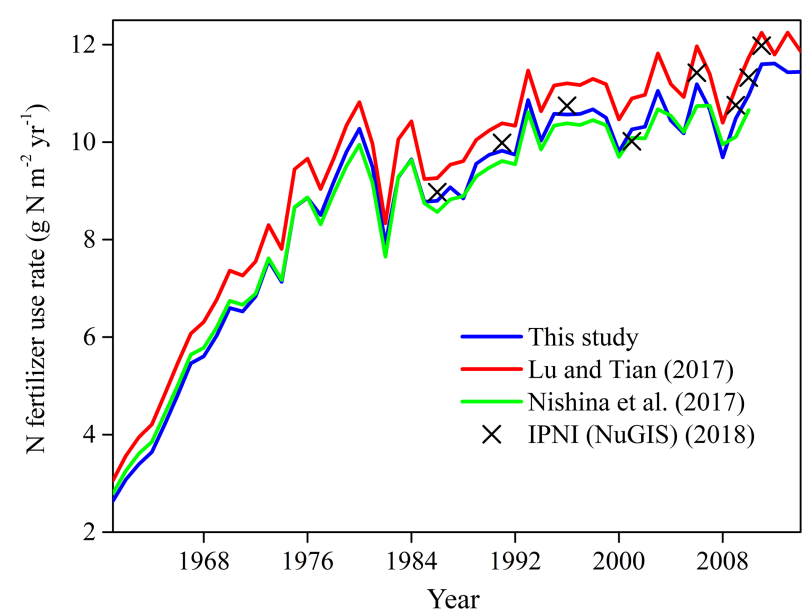

Figure 8. Time series of $\mathrm{N}$ fertilizer use in the US: national commercial $\mathrm{N}$ fertilizer consumption in the US from 1961 to 2014 derived from four datasets. Red line: this study; green line: Lu and Tian (2017); blue line: Nishina et al. (2017); and ×: IPNI (2018). The $\mathrm{N}$ fertilizer consumption derived from $\mathrm{Lu}$ and Tian (2017) covers all states and territories of the US, whereas the other three datasets only cover the contiguous US.

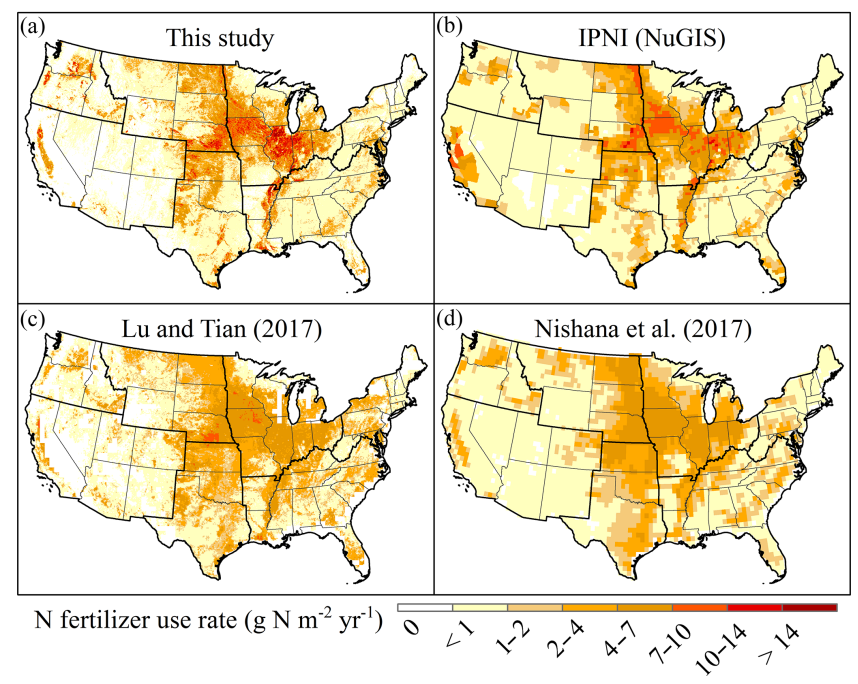

Figure 9. Comparison of $\mathrm{N}$ fertilizer use rates across the contiguous US in 2010. (a) This study; (b) IPNI (2018); (c) Lu and Tian (2017); and (d) Nishina et al. (2017).

use. The overall pattern of $\mathrm{N}$ fertilizer use from our study is similar to Ruddy et al. (2006), indicating hotspots of $\mathrm{N}$ fertilizer use $\left(>8 \mathrm{~g} \mathrm{~N} \mathrm{~m}^{-2} \mathrm{yr}^{-1}\right)$ in the Midwest, on the west and east coast, and in some parts of the Northwest, the Southern Great Plains, Nebraska, California, Texas, and Florida (Supplement Fig. S6). Nevertheless, the higher N use rates in California, southern Florida, and eastern North Carolina (> $8 \mathrm{~g} \mathrm{~N} \mathrm{~m}^{-2} \mathrm{yr}^{-1}$ in Ruddy et al. (2006) and 2$6 \mathrm{~g} \mathrm{~N} \mathrm{~m}^{-2} \mathrm{yr}^{-1}$ in our study) displayed in Ruddy et al. (2006) may be caused by amplified fertilizer use in areas with low cropland coverage, whilst our maps removed such "apparent peaks" by accounting for cropland density in each grid cell. In comparison, the $\mathrm{N}$ use rate of Indiana and Ohio (4$8 \mathrm{~g} \mathrm{~N} \mathrm{~m}^{-2} \mathrm{yr}^{-1}$ in Ruddy et al., 2006) is lower than that in our study $\left(>8 \mathrm{~g} \mathrm{~N} \mathrm{~m}^{-2} \mathrm{yr}^{-1}\right)$. This may be caused by using the fixed cropland map from the year 1992 instead of the 1997 map in their study and overlooking cropland area change information between years. In addition, our map provides more detail on spatial heterogeneity by adopting state-level cropspecific $\mathrm{N}$ fertilizer application rates in each state and generating spatial maps based on $1 \mathrm{~km}$ land use history data (Yu and $\mathrm{Lu}, 2017)$. Thus, our map is advantageous in that it can characterize cross-crop differences in using $\mathrm{N}$ fertilizers, especially in intensively cultivated regions, such as the Midwest, the Great Plains, and southern Southeast.

We further compared the ratios of $\mathrm{N}$ application timing across corn, cotton, spring wheat, and winter wheat nationwide with the report provided by Wade et al. (2015), in which nitrogen management practices were reported regionally and nationally across the US (Supplement Table S9). Overall, the differences between our study and Wade et al. (2015) range between 0 and $6 \%$, with the largest difference found in afterplanting fertilizer use in cotton (6\%). In our study, the application timing showed that the majority of $\mathrm{N}$ applied in spring was found in corn (50\%) and spring wheat $(43 \%)$, in which fall application accounts for the second largest share of annual fertilizer consumption (18\% for corn and $22 \%$ for spring wheat). In comparison, cotton and winter wheat producers applied 53 and $44 \%$ of $\mathrm{N}$ after planting, respectively. According to Bierman et al. (2012), corn in Minnesota received 32.5 and $58.8 \%$ of $\mathrm{N}$ fertilizer in fall of 2008 and spring of 2009, respectively, which is close to our estimates (31.9\% in fall and $59.2 \%$ in spring). These comparisons imply that $\mathrm{N}$ fertilizer application timing across the nation and across crops was well depicted in our study.

\subsection{Temporal and spatial change in nitrogen fertilizer use}

Compared to natural organic $\mathrm{N}$ fertilizer, chemical $\mathrm{N}$ fertilizer gradually became the major agricultural $\mathrm{N}$ input in the US from $1850(6.67 \%)$ to $1930(83.86 \%)$; however, the total consumption and per unit area rate during this period were still low (Mehring et al., 1957). Although cropland area declined between 1940 and 1970, especially for corn and cotton (Gunjal et al., 1980; Nickerson et al., 2011), the total N consumption at a national scale had been increasing as the result of the rising $\mathrm{N}$ fertilizer use rate and widespread adoption of $\mathrm{N}$ fertilizer (Beddow, 2012) along the west coast, the Southeast, the Southern Great Plains, and the Midwest. With the expansion of cropland to 383 million acres in 1982 (Nickerson et al., 2011), in addition to the marked increase in the application rate of all crops except cotton, the major agricultural regions received a tremendous amount of $\mathrm{N}$ during 1970-1985, except for the conspicuous drop in the year 1983 
due to large cropland abandonment (i.e., cropland converted to other land use types, Yu and Lu, 2017). Driven by a change in grain demand and fertilizer prices, $\mathrm{N}$ fertilizer use in the US gradually increased; however, there have been fluctuations since 1985, such as the drop in $\mathrm{N}$ fertilizer consumption in 2008-2009, which may have been due to the high price of $\mathrm{N}$ fertilizer caused by the 2008 financial crisis (USDA-ERS, 2013). The increase in $\mathrm{N}$ fertilizer use in the seven regions throughout the US can be attributed to different driving factors. For example, the increase of $\mathrm{N}$ use in regions dominated by spring wheat and rice, such as the northern regions of the Northern Great Plains, western regions of the Southeast, and southern Texas, were largely due to the increased fertilizer use rate. In contrast, the increases in the Midwest and southern regions of the Northern Great Plains were mainly due to corn expansion ( $\mathrm{Yu}$ and $\mathrm{Lu}, 2017$ ), while the $\mathrm{N}$ use rate of corn has been relatively high and stable since the 1980s. Along with the rise in $\mathrm{N}$ fertilizer use, the fraction of $\mathrm{NH}_{4}^{+}$$\mathrm{N}$ to total $\mathrm{N}$ use also increased from 1900 to the present day. Before the 1960s, the fraction varied greatly among the seven regions of the US due to the different species of $\mathrm{N}$ fertilizers used, which may have been determined by fertilizer prices, farmer preference, and cultivated crop types, among other factors. Since the $1970 \mathrm{~s}$, the $\mathrm{NH}_{4}^{+}-\mathrm{N}$ fraction has remained at a high level $(>80 \%)$ across the US, which may largely lower the risk of $\mathrm{N}$ leaching (Gentry et al., 1998). Conversely, it may also increase the potential for $\mathrm{N}$ loss through ammonia volatilization. In addition, the shift from multiple $\mathrm{NH}_{4}^{+}-\mathrm{N}$ fertilizers to single $\mathrm{NH}_{4}^{+}-\mathrm{N}$ fertilizers with high $\mathrm{N}$ concentrations since the 1960s may also enhance the risk of gaseous $\mathrm{N}$ emission due to large amounts of $\mathrm{N}$ being available in soil (Harrison and Webb, 2001).

The winter wheat in the Southern Great Plains and the northern region of the Northwest received most of its annual ammonium $\mathrm{N}$ and nitrate $\mathrm{N}$ fertilizer in fall, which contributed to the growing grain yield (Mahler et al., 1994). Corn in the Midwest, however, especially in Minnesota, Iowa, and Illinois, received over $30 \%$ of its annual $\mathrm{NH}_{4}^{+}-\mathrm{N}$ in fall, implying a high potential for $\mathrm{N}$ loss in this region (Dinnes et al., 2002; Parkin and Hatfield, 2010). Corn farmers that adopted fall application in the Midwest usually applied nitrification inhibitor with fertilizer; however, sudden $\mathrm{NH}_{4}^{+}-\mathrm{N}$ input exceeding plant demands may cause tremendous ammonia volatilization (Sommer et al., 2004). Soybean and winter wheat in the Midwest, northern regions of the Southeast, and eastern sections of the Northern Great Plains received more than $65 \%$ of $\mathrm{N}$ fertilizer in fall, which is after planting for winter wheat. However, due to the large planting area of corn with two-fold higher $\mathrm{N}$ application rates than other crops, these regions are still characterized by high $\mathrm{N}$ fertilizer input in spring. According to the USDA, spring application of $\mathrm{N}$ fertilizer occurs approximately 1 month before planting, which may cause large amounts of $\mathrm{N}$ to be lost through processes such as leaching of soluble nitrate; this leaching is triggered by intense rainfall in spring, contribut- ing to hypoxia in the Gulf of Mexico (Goolsby et al., 2001). In comparison, fertilizer use for spring wheat and barley were only found at-planting in Montana and North Dakota in the form of ammonium N. Moreover, cotton farmers along the southeast coast and in western Texas preferred to apply both ammonium- and nitrate-form fertilizer after planting, which is also the case for corn and cotton farmers in Ohio and Nebraska and winter wheat in the Southern Great Plains.

\subsection{Uncertainty and future research needs}

The uncertainties of this database are mainly due to the following: (1) $\mathrm{N}$ fertilizer use in nine major crops and cropland pasture combined accounts for nearly $85 \%$ of the national agricultural fertilizer consumption (excluding $\mathrm{N}$ fertilizer use in permanent pasture and non-farm areas, Table S2 in the Supplement), and the rest fertilizer goes to other crops. We grouped these crops (e.g., oilseeds, sugar crops, vegetables, fruits, other grains) into the category "others" and equally assigned the rest $\mathrm{N}$ fertilizer amount (rate, application timing, and the fraction of $\mathrm{NH}_{4}^{+}-\mathrm{N}$ and $\mathrm{NO}_{3}^{-}-\mathrm{N}$ ) to all the crops within this category. This may bias the estimated $\mathrm{N}$ fertilizer use of some crop types. (2) Due to the paucity of finer resolution information, state-level crop-specific $\mathrm{N}$ management data (rate, application timing, and the fraction of $\mathrm{NH}_{4}^{+}-\mathrm{N}$ and $\mathrm{NO}_{3}^{-}-\mathrm{N}$ ) were obtained to characterize the way in which farmers use fertilizer to maximize their profits. Although this is the best data we can obtain for national coverage, crop-specific practices, and centurial duration, sub-state (e.g., county) details are still lacking. (3) Timing information regarding the crop-specific $\mathrm{N}$ application derived from the latest survey years was assumed unchanged over time due to the lack of interannual survey data. This assumption may cause an underestimation of the fall application before the 2000s, as urea and N solution-forms of N, which are suitable for spring application, have been increasingly used to replace fall-applied anhydrous ammonia since the 1960s (Randall and Sawyer, 2008). (4) To separate the amount of $\mathrm{NH}_{4}^{+}-\mathrm{N}$ and $\mathrm{NO}_{3}^{-}-\mathrm{N}$ in fertilizer use, we adopted the $\mathrm{N}$ form fraction of 11 major single $\mathrm{N}$ fertilizer types, which accounted for $85 \%$ of the N consumption in the US after the 1980s, and assumed the $\mathrm{NH}_{4}^{+}-\mathrm{N}$ : $\mathrm{NO}_{3}^{-}-\mathrm{N}$ ratio was 1:1 for the rest fertilizer types (Supplement Fig. S7). However, mixed N fertilizers were favored before single $\mathrm{N}$ fertilizers became popular (Sheridan, 1979). The temporal change of the $\mathrm{NH}_{4}^{+}-\mathrm{N}$ fraction in mixed $\mathrm{N}$ fertilizer before the 1980s may be biased in estimations. For example, ammonium $\mathrm{N}$ only accounted for $2 \%$ of mixed fertilizer $\mathrm{N}$ in 1900 , but has been favored since 1925 and gradually rose to $72 \%$ of mixed $\mathrm{N}$ fertilizer by 1944 (Mehring et al., 1946). (5) The $\mathrm{NH}_{4}^{+}-\mathrm{N}$ fraction was assumed to be constant across crop types in each state in a year. This may cause biases because farmers may apply different type of $\mathrm{N}$ fertilizers to different crops. For example, $\mathrm{NH}_{4}^{+}-\mathrm{N}$ was favored in rice paddies due to higher oxidizability and the tendency toward $\mathrm{N}$ loss via denitrification from $\mathrm{NO}_{3}^{-}-\mathrm{N}$, 
implying a higher $\mathrm{NH}_{4}^{+}-\mathrm{N}$ fraction in the $\mathrm{N}$ fertilizer of rice (Norman et al., 2003). (6) The historical crop type maps were reconstructed using USDA survey data at state-level. However, the spatial distribution of $\mathrm{N}$ fertilizer use was uncertain at a sub-state level due to the lack of finer scale data for crop type map reconstruction. Therefore, a finer-scale spatial survey of crop-specific $\mathrm{N}$ fertilizer use (e.g., county-level), annual application timing data, and the development of cropspecific fractions of $\mathrm{NH}_{4}^{+}-\mathrm{N}$ and $\mathrm{NO}_{3}^{-}-\mathrm{N}$ data will be beneficial for further improving the characterization of geospatial and temporal patterns of $\mathrm{N}$ fertilizer management in the US.

\section{Data availability}

The $\mathrm{N}$ fertilizer use dataset is publicly available via PANGAEA at https://doi.org/10.1594/PANGAEA.883585 (Cao et al., 2017).

\section{Conclusion}

Nitrogen fertilizer management (e.g., $\mathrm{N}$ fertilizer use rate, application timing, and the fraction of $\mathrm{NH}_{4}^{+}-\mathrm{N}$ and $\mathrm{NO}_{3}^{-}-\mathrm{N}$ ) is a critical component of agricultural practices which significantly promotes crop yield. The dataset developed in this study enables us to explore the spatiotemporal pattern of $\mathrm{N}$ fertilizer management across the US. N fertilizer consumption, as well as $\mathrm{N}$ fertilizer use rate increased tremendously from 1850 to 2015, but the magnitude varied among crop types. Meanwhile, hotspots of $\mathrm{N}$ fertilizer use has shifted from the southeastern and eastern US to the Midwest, the Great Plains, and the Northwest of the US since the 1940s. In addition, the majority of $\mathrm{N}$ fertilizer was applied in spring, approximately 1 month before planting. Moreover, considerable amount of $\mathrm{N}$ fertilizer was applied in fall of the previous year, which implies a high risk of gaseous $\mathrm{N}$ emission and $\mathrm{N}$ leaching. The fraction of $\mathrm{NH}_{4}^{+}-\mathrm{N}$ to total $\mathrm{N}$ varied greatly among the seven regions of the US before the 1960s, while $\mathrm{NH}_{4}^{+}-\mathrm{N}$ gained popularity and dominated $\mathrm{N}$ fertilizer use after the 1970s, which reduced the potential of N loading while increasing the ammonia volatilization risk. The appropriate configuration of $\mathrm{N}$ fertilizer use according to precise fertilizer demands should be encouraged to improve NUE and thus reduce associated environmental and ecological problems.

\section{The Supplement related to this article is available online at https://doi.org/10.5194/essd-10-969-2018-supplement.}

Competing interests. The authors declare that they have no conflict of interest.
Acknowledgements. This work was supported by a seed grant from Iowa Nutrient Research Center and new faculty start-up fund from Iowa State University.

Edited by: David Carlson

Reviewed by: two anonymous referees

\section{References}

Alexander, R. B. and Smith, R. A.: County level estimates of nitrogen and phosphorus fertilizer use in the United States, 1945 to 1985, U.S. Geological Survey, Books and Open-File Reports [distributor] No. 90-130, Reston, Virginia, USA, 1990.

Alexandratos, N. and Bruinsma, J.: World agriculture towards 2030/2050: the 2012 Revision, ESA Working paper No. 12-03, FAO, Rome, Italy, 2012.

Association of American Plant Food Control Officials (AAPFCO): Commercial Fertilizers (1986, 1996, 2006, 2012), available at: http://www.aapfco.org/publications.html, last access: 19 November 2017.

Azam, F., Müller, C., Weiske, A., Benckiser, G., and Ottow, J.: Nitrification and denitrification as sources of atmospheric nitrous oxide-role of oxidizable carbon and applied nitrogen, Biol. Fert. Soils, 35, 54-61, 2002.

Beddow, J. M.: A bio-economic assessment of the spatial dynamics of US corn production and yields, $\mathrm{PhD}$ thesis, University of Minnesota, Minneapolis, Minnesota, USA, 2012.

Bierman, P. M., Rosen, C. J., Venterea, R. T., and Lamb, J. A.: Survey of nitrogen fertilizer use on corn in Minnesota, Agr. Syst., 109, 43-52, 2012.

Bouwman, A. F., Boumans, L. J. M., and Batjes, N. H.: Emissions of $\mathrm{N}_{2} \mathrm{O}$ and NO from fertilized fields: Summary of available measurement data, Global Biogeochem. Cy., 16, 6-1-6-13, 2002.

Bowman, W. D., Cleveland, C. C., Halada, L., Hreško, J., and Baron, J. S.: Negative impact of nitrogen deposition on soil buffering capacity, Nat. Geosci., 1, 767-770, 2008.

Brakebill, J. W. and Gronberg, J. M.: County-Level Estimates of Nitrogen and Phosphorus from Commercial Fertilizer for the Conterminous United States, 1987-2012, U.S. Geological Survey data release, available at: https://doi.org/10.5066/F7H41PKX, 2017.

Burch, J. A. and Fox, R. H.: The effect of temperature and initial soil moisture content on the volatilization of ammonia from surfaceapplied urea, Soil Sci., 147, 311-318, 1989.

Cao, P., Lu, C., and Yu, Z.: Agricultural nitrogen fertilizer uses in the continental U.S. during 18502015: a set of gridded time-series data, PANGAEA, https://doi.org/10.1594/PANGAEA.883585, 2017.

Cassman, K. G., Dobermann, D., and Walters, D. T.: Agroecosystems, nitrogen-use efficiency, and nitrogen management, AMBIO, 31, 132-140, 2002.

Ciampitti, I. A. and Vyn, T. J.: Understanding global and historical nutrient use efficiencies for closing maize yield gaps, Agron. J., 106, 2107-2117, 2014. 
Davidson, E. A.: The contribution of manure and fertilizer nitrogen to atmospheric nitrous oxide since 1860, Nat. Geosci., 2, 659662, 2009.

Deryng, D., Sacks, W. J., Barford, C. C., and Ramankutty, N.: Simulating the effects of climate and agricultural management practices on global crop yield, Global Biogeochem. Cy., 25, 96-101, 2011.

Dinnes, D. L., Karlen, D. L., Jaynes, D. B., Kaspar, T. C., Hatfield, J. L., Colvin, T. S., and Cambardella, C. A.: Nitrogen management strategies to reduce nitrate leaching in tile-drained midwestern soils, Agron. J., 94, 153-171, 2002.

Erisman, J. W., Sutton, M. A., Galloway, J., Klimont, Z., and Winiwarter, W.: How a century of ammonia synthesis changed the world, Nat. Geosci., 1, 636-639, 2008.

FAO (Food and Agriculture Organization of the United Nations): FAO online database, available at: http://www.fao.org/faostat/en/ \#data/RF, last access: 19 October 2017.

Follett, J. R., Follett, R. F., and Herz, W. C.: Environmental and Human Impacts of Reactive Nitrogen, Adv. Nitr. Managem. Water Qual., SWCS, Ankeny, Iowa, USA, 2010.

Galloway, J. N., Aber, J. D., Erisman, J. W., Seitzinger, S. P., Howarth, R. W., Cowling, E. B., and Cosby, B. J.: The Nitrogen Cascade, BioScience, 53, 341-356, 2003.

Gentry, L. E., David, M. B., Smith, K. M., and Kovacic, D. A.: Nitrogen cycling and tile drainage nitrate loss in a corn/soybean watershed, Agr. Ecosyst. Environ., 68, 85-97, 1998.

Goebes, M. D., Strader, R., and Davidson, C.: An ammonia emission inventory for fertilizer application in the United States, Atmos. Environ., 37, 2539-2550, 2003.

Goolsby, D. A., Battaglin, W. A., Aulenbach, B. T., and Hooper, R. P.: Nitrogen input to the Gulf of Mexico, J. Environ. Qual., 30, 329-336, 2001.

Gunjal, K. R., Roberts, R. K., and Heady, E. O.: Fertilizer demand functions for five crops in the United States, Southern J. Agric. Econ., 12, 111-116, 1980.

Hao, X., Chang, C., Carefoot, J. M., Janzen, H. H., and Ellert, B. H.: Nitrous oxide emissions from an irrigated soil as affected by fertilizer and straw management, Nutr. Cycl. Agroecosys., 60, $1-8,2001$.

Harrison, R. and Webb, J.: A review of the effect of $\mathrm{N}$ fertilizer type on gaseous emissions, Adv. Agron., 73, 65-108, 2001.

He, Z. L., Alva, A. K., Calvert, D. V., and Banks, D. J.: Ammonia Volatilization from Different Fertilizer Sources and Effects of Temperature and Soil pH1, Soil Sci., 164, 750-758, 1999.

Heffer, P., Gruère, A., and Roberts, T.: Assessment of Fertilizer Use by Crop at the Global Level 2014-2014/15, International Fertilizer Association (IFA) and International Plant Nutrition Institute (IPNI) Report A/17/134 rev, available at: https://www.fertilizer.org/En/Statistics/ Agriculture_Databases/Agriculture_Committee_Databases. aspx?New_ContentCollectionOrganizerCommon=1\#New_ ContentCollectionOrganizerCommon (last access: 16 March 2018), 2017.

Hoben, J. P., Gehl, R. J., Millar, N., Grace, P. R., and Robertson, G. P.: Nonlinear nitrous oxide $\left(\mathrm{N}_{2} \mathrm{O}\right)$ response to nitrogen fertilizer in on-farm corn crops of the US Midwest, Glob. Change Biol., 17, 1140-1152, 2011.

Hurtt, G., Chini, L. P., Frolking, S., Betts, R., Feddema, J., Fischer, G., Fisk, J., Hibbard, K., Houghton, R., Janetos, A., Jones, C.
D., Kindermann, G., Kinoshita, T., Klein Goldewijk, K., Riahi, K., Shevliakova, E., Smith, S., Stehfest, E., Thomson, A., Thornton, P., van Vuuren, D. P., and Wang, Y. P.: Harmonization of land-use scenarios for the period 1500-2100: 600 years of global gridded annual land-use transitions, wood harvest, and resulting secondary lands, Climatic Change, 109, 117-161, 2011.

Ibach, D. B. and Adams, J. R.: Fertilizer Use in the United States by Crops and Areas, 1964 Estimates, USDA-Economic Research Service and Statistical Reporting Service, Statistical Bulletin No. 408, Washington, D.C., USA, 1967.

Ibach, D. B., Adams, J. R., and Fox, E. I.: Commercial Fertilizer Used on Crops and Pasture in the United States, 1959 Estimates, USDA-Economic Research Service and Agricultural Research Service, Statistical Bulletin No. 348, Washington, D.C., USA, 1964.

IPNI (International Plant Nutrition Institute): A Nutrient Use Information System (NuGIS) for the U.S. Norcross, GA, 1 November 2011, available at: www.ipni.net/nugis, last access: 1 March 2018.

Jarvis, S. C. and Pain, B. F.: Ammonia volatilization from agricultural land, Proceedings-Fertiliser Soc., 298, 1-35, 1990.

Jaynes, D. B., Colvin, T. S., Karlen, D. L., Cambardella, C. A., and Meek, D. W.: Nitrate loss in subsurface drainage as affected by nitrogen fertilizer rate, J. Environ. Qual., 30, 1305-1314, 2001.

Keller, G. D. and Mengel, D. B.: Ammonia Volatilization from Nitrogen Fertilizers Surface Applied to No-till Corn, Soil Sci. Soc. Am. J., 50, 1060-1063, 1986.

Klein Goldewijk, K.: A historical land use data set for the Holocene, HYDE 3.2, DANS, https://doi.org/10.17026/dansznk-cfy3, 2016.

Lu, C. and Tian, H.: Global nitrogen and phosphorus fertilizer use for agriculture production in the past half century: shifted hot spots and nutrient imbalance, Earth Syst. Sci. Data, 9, 181-192, https://doi.org/10.5194/essd-9-181-2017, 2017.

Mahler, R. L., Koehler, F. E., and Lutcher, L. K.: Nitrogen Source, Timing of Application, and Placement: Effects on Winter Wheat Production, Agron. J., 86, 637-642, 1994.

Mcisaac, G. F., David, M. B., Gertner, G. Z., McIsaac, G. F., David, M. B., Gertner, G. Z., and Goolsby, D. A.: Nitrate flux in the Mississippi River, Nature, 414, 166-167, 2001.

Mehring, A. L., Wallace, H. M., and Drain, M.: Consumption and trends in the use of fertilizer in the year ended June 30, 1944, USDA, Washington, D.C., USA, 1946.

Mehring, A. L., Adams, J. R., and Jacob, K. D.: Statistics on Fertilizers and Liming Materials in the United States, USDAAgricultural Research Service, Statistical Bulletin No. 191, Washington, D.C., USA, 1957.

Mengel, D. B.: Types and Uses of Nitrogen Fertilizers for Crop Production, available at: https://www.extension.purdue. edu/extmedia/AY/AY-204.html, last access: 19 November 2017.

Millar, N., Robertson, G. P., Grace, P. R., Gehl, R. J., and Hoben, J. P.: Nitrogen fertilizer management for nitrous oxide $\left(\mathrm{N}_{2} \mathrm{O}\right)$ mitigation in intensive corn (Maize) production: an emissions reduction protocol for US Midwest agriculture, Mitig. Adapt. Strat. Gl., 15, 185-204, 2010.

Mueller, N. D., Gerber, J. S., Johnston, M., Ray, D. K., Ramankutty, N., and Foley, J. A.: Closing yield gaps through nutrient and water management, Nature, 490, 254-257, 2012. 
Nakagaki, N. and Wolock, D. M.: Estimation of agricultural pesticide use in drainage basins using land cover maps and county pesticide data, U.S. Geological Survey Open File Rep. 20051188, Reston, Virginia, USA, 46 pp., 2005.

Nickerson, C., Ebel, R., Borchers, A., and Carriazo, F.: Major uses of land in the United States, 2007, USDA, Economic Research Service, available at: https://www.ers.usda.gov/ publications/pub-details/?pubid=44630 (last access: 19 October 2017), 2011.

Nishina, K., Ito, A., Hanasaki, N., and Hayashi, S.: Reconstruction of spatially detailed global map of $\mathrm{NH}_{4}^{+}$and $\mathrm{NO}_{3}^{-}$application in synthetic nitrogen fertilizer, Earth Syst. Sci. Data, 9, 149-162, https://doi.org/10.5194/essd-9-149-2017, 2017.

Norman, R. J., Wilson Jr., C. E., and Slaton, N. A.: Soil fertilization and mineral nutrition in U.S. mechanized rice culture, in: Rice: Origin, history, technology, and production, edited by: Smith, C. W. and Dilday, R. H., John Wiley \& Sons, Hoboken, New Jersey, USA, 331-411, 2003.

Parkin, T. B. and Hatfield, J. L.: Influence of nitrapyrin on $\mathrm{N}_{2} \mathrm{O}$ losses from soil receiving fall-applied anhydrous ammonia, Agr. Ecosyst. Environ., 136, 81-86, 2010.

Randall, G. W. and Sawyer, J. E.: Nitrogen application timing, forms and additives, in: Final Report: Gulf Hypoxia and Local Water Quality Concerns Workshop, Upper Mississippi River Sub-Basin Hypoxia Nutrient Committee, American Society of Agricultural and Biological Engineers, St. Joseph, Michigan, USA, 73-85, 2008.

Randall, G. W., Vetsch, J. A., and Huffman, J. R.: Nitrate losses in subsurface drainage from a corn-soybean rotation as affected by time of nitrogen application and use of nitrapyrin, J. Environ. Qual., 32, 1764-1772, 2003.

Ray, D. K., Mueller, N. D., West, P. C., and Foley, J. A.: Yield Trends Are Insufficient to Double Global Crop Production by 2050, Plos One, 8, e66428, https://doi.org/10.1371/journal.pone.0066428, 2013.

Ruddy, B. C., Lorenz, D. L., and Mueller, D. K.: County-level estimates of nutrient inputs to the land surface of the conterminous United States, 1982-2001, USGS Scientific Investigations Report 2006-5012, 17 pp., available at: http://pubs.usgs.gov/sir/ 2006/5012/ (last access: 19 November 2017), 2006.

Sheridan, R. C.: Chemical fertilizers in southern agriculture, Agr. Hist., 53, 308-318, 1979.

Smil, V.: Nitrogen in crop production: An account of global flows, Global Biogeochem. Cy., 13, 647-662, 1999.

Snyder, C. S., Bruulsema, T. W., Jensen, T. L., and Fixen, P. E.: Review of greenhouse gas emissions from crop production systems and fertilizer management effects, Agr. Ecosys. Environ., 133, 247-266, 2009.

Sommer, S. G., Schjoerring, J. K., and Denmead, O. T.: Ammonia emission from mineral fertilizers and fertilized crops, Adv. Agron., 82, 557-622, 2004.

Stewart, W. M., Dibb, D. W., Johnston, A. E., and Smyth, T. J.: The Contribution of Commercial Fertilizer Nutrients to Food Production, Agron. J., 97, 1-6, 2005.

Tenuta, M. and Beauchamp, E. G.: Nitrous oxide production from granular nitrogen fertilizers applied to a silt loam soil, Can. J. Soil Sci., 83, 521-532, 2003.
Tilman, D., Cassman, K. G., Matson, P. A., Naylor, R., and Polasky, S.: Agricultural sustainability and intensive production practices, Nature, 418, 671-677, 2002.

USDA (U.S. Department of Agriculture): Fertilizer Used on Crops and Pasture in the United States, 1954 Estimates, USDAAgricultural Research Service, Statistical Bulletin No. 216, Washington, D.C., USA, 1957.

USDA (U.S. Department of Agriculture): Consumption of Commercial Fertilizers and Primary Plant Nutrients in the United States, 1850-1964, and by STATES, 1945-64, USDA-Statistical Reporting Service, Crop Reporting Board, Statistical Bulletin No. 375, Washington, D.C., USA, 1966.

USDA (U.S. Department of Agriculture): Consumption of Commercial Fertilizers, Primary Plant Nutrients, and Micronutrients, 1850-1969, USDA-Statistical Reporting Service, Crop Reporting Board, Statistical Bulletin No. 472, Washington, D.C., USA, 1971.

USDA (U.S. Department of Agriculture): Commercial fertilizers consumption for year ended June 30, USDA-Statistical Reporting Service, Crop Reporting Board, Washington, D.C., USA, 1977.

USDA-ERS (U.S. Department of Agriculture-Economic Research Service): Fertilizer Use and Price, available at: https://www.ers.usda.gov/data-products/ arms-farm-financial-and-crop-production-practices/ (last access: 19 November 2017), 2013.

USDA-ERS (U.S. Department of Agriculture-Economic Research Service): Tailored Reports: Crop Production Practices, available at: https://www.ers.usda.gov/data-products/ fertilizer-use-and-price/ (last access: 19 November 2017), 2016.

USDA-NASS (U.S. Department of Agriculture-National Agricultural Statistics Service): Agricultural Chemical Use Program, available at: https://www.nass.usda.gov/Surveys/Guide_ to_NASS_Surveys/Chemical_Use/index.php, last access: 19 November 2017.

USDA-NRCS (U.S. Department of Agriculture-Natural Resources Conservation Service): Nitrogen Fertilizer Guide, available at: https://prod.nrcs.usda.gov/Internet/FSE_DOCUMENTS/ nrcs144p2_068185.pdf, last access: 19 November 2017.

U.S. Fourth National Climate Assessment, available at: http://www. globalchange.gov/nca4, last access: 19 November 2017.

Van Grinsven, H. J., Bouwman, L., Cassman, K. G., Van Es, H. M., McCrackin, M. L., and Beusen, A. H.: Losses of Ammonia and Nitrate from Agriculture and Their Effect on Nitrogen Recovery in the European Union and the United States between 1900 and 2050, J. Environ. Qual., 44, 356-367, 2015.

Venterea, R. T. and Stanenas, A. J.: Profile analysis and modeling of reduced tillage effects on soil nitrous oxide flux, J. Environ. Qual., 37, 1360-1367, 2008.

Vlek, P. L. G. and Craswell, E. T.: Effect of Nitrogen Source and Management on Ammonia Volatilization Losses from Flooded Rice-Soil System, Soil Sci. Soc. Am. J., 43, 352-358, 1979.

Wade, T., Claassen, R., and Wallander, S.: Conservation-practice adoption rates vary widely by crop and region, U.S. Department of Agriculture-Economic Research Service, EIB-147, available at: https://www.ers.usda.gov/publications/pub-details/ ?pubid=44030 (last access: 19 November 2017), 2015.

Yu, Z. and Lu, C. Q.: Historical cropland expansion and abandonment in the continental U.S. during 1850 to 2015, Glob. Ecol. 
Biogeogr., 27, 322-333, https://doi.org/10.1111/geb.12697, 2017.

Yu, Z., Lu, C., Cao, P., and Tian, H.: Long-term terrestrial carbon dynamics in the Midwestern United States during 1850-2015: Roles of land use and cover change and agricultural management, Glob. Change Biol., 24, 2673-2690, https://doi.org/10.1111/gcb.14074, 2018.
Zhang, X., Davidson, E. A., and Mauzerall, D. L., Searchinger, T. D., Dumas, P., and Shen, Y.: Managing nitrogen for sustainable development, Nature, 528, 51-59, 2015. 